\title{
¿Sirve el tráfico ilícito de bienes culturales para financiar el terrorismo?
}

\author{
Does the illicit trafficking of cultural goods fund \\ terrorism?
}

El presente trabajo analiza en profundidad las vías de financiación del grupo terrorista DAESH para determinar en qué medida la extracción, comercialización y tráfico ilícito de bienes culturales procedentes de las zonas de ocupación se empleaban como fuente de financiación de sus actividades. Asimismo, estudia el impacto de estas conductas en el mercado de arte y antigüedades europeo, con especial atención a un caso descubierto en España que parecía estar vinculado con redes de comercio ilegal de piezas procedentes de zonas en conflicto. La finalidad es determinar la extensión de estas redes de mercadeo y el impacto económico en la actuación de DAESH, tanto para entender su modus operandi como para desarrollar medidas proteccionistas que ayuden a combatir estas prácticas ahora y en el futuro.

Palabras clave: tráfico ilícito, bienes culturales, financiación del terrorismo, DAESH, protección del patrimonio cultural.
This paper is an in depth examination of the means of finance of the terrorist group DAESH so as to determine to what extent the plunder, commercialisation and illicit trafficking of cultural goods from the zones it occupies serve to fund its activities. The study also delves into the impact of these activities on the European art and antique market, with special attention given to a case uncovered in Spain apparently linked to illegal traffic networks from zones of conflict. The intention is to determine the scope of DAESH's networks and their economic impact so as to pinpoint both its modus operandi and develop measures to combat it today and in the future.

Keywords: Illicit trafficking, cultural goods, terrorism funding, DAESH, cultural heritage protection. 


\section{Contexto bélico y peligro para el patrimonio cultural}

Un breve repaso a nuestra historia revela que la destrucción de bienes culturales ha sido siempre una práctica intrínseca a todo enfrentamiento armado. El ataque a monumentos, lugares de culto o edificios históricos posee un valor simbólico y propagandístico de gran calado. Se trata de una acción física que evidencia la derrota del oponente y materializa el acto de ocupación, la dominación del vencedor sobre el vencido. Al mismo tiempo, estas prácticas consolidan la victoria moral sobre el colectivo derrotado, todo ello acompañado de un aprovechamiento interesado de sus riquezas y objetos valiosos. La parte más dañina, no obstante, es la que busca conscientemente aniquilar su identidad histórica y cultural, para que en el futuro no se pueda recordar aquello que ha sido eliminado y que representaba el esplendor y la herencia de toda una civilización.

El patrimonio cultural se ve amenazado en numerosas ocasiones, tanto en tiempos de paz como en tiempos de guerra, si bien en este último caso los efectos destructivos suelen concentrarse de manera dramática. Es por todos conocido que el saqueo y la apropiación de las riquezas y tesoros de la potencia vencida eran una práctica asentada en el desarrollo de todo conflicto bélico. El cuestionamiento sobre dónde debe estar el límite en los usos de la guerra a la hora de destruir los bienes ajenos comenzó a plantearse en el contexto de la Guerra de Secesión norteamericana con el conocido Código Lieber. Los avances introducidos por este texto, y los siguientes que recogieron su testigo, resultaron ser tímidas propuestas a la hora de restringir las acciones destructivas del patrimonio cultural que tuvieron lugar en conflictos posteriores, sobre todo durante la Segunda Guerra Mundial. La insuficiencia de estas disposiciones y recomendaciones junto con el demoledor impacto de las pérdidas sufridas en esta guerra inclinaron al conjunto de la comunidad internacional a ratificar unas pautas que salvaguardasen los bienes culturales en el curso de un enfrentamiento bélico. Todo ello desembocó en la Convención para la Protección de los Bienes Culturales en Caso de Conflicto Armado, adoptada en La Haya en 1954.

En relación con esta Convención es importante señalar que, en cierta medida, este instrumento es un documento reaccionario frente a los desastres acaecidos durante la Segunda Guerra Mundial, si bien su grado de innovación jurídica es relativamente escaso en comparación con los textos que le sirvieron de antecedente. El deber de no atacar edificios históricos y monumentos salvo que concurriese una imperiosa necesidad militar, por ejemplo, era una pauta sostenida desde principios del siglo pasado que, sin embargo, fue deliberadamente obviada en el transcurso de esta guerra, de ahí que la Convención de 1954 volviese a reiterar esta obligación. Otra de las grandes contribuciones de este texto fue la de poner en valor el patrimonio cultural no solo para la nación que lo alberga, sino para toda la comunidad internacional. La afirmación de que estos bienes enriquecen la cultura mundial fue otra de las ideas claves desarrolladas por este instrumento. De aquí se deriva la obligación de todos los estados de respetar y preservar los bienes culturales, ya que integran el "patrimonio cultural de toda la humanidad, puesto que cada pueblo aporta su contribución a la cultura mundial", como enuncia su preámbulo.

A pesar del amplio consenso internacional que condujo a la aprobación de este instrumento, algunos casos devastadores ocurridos en los últimos cincuenta años pusieron en tela de juicio la operatividad de este texto y de la conciencia que se tiene respecto a la necesidad de proteger los bienes culturales, como en el caso del conflicto de Bosnia-Herzegovina o la guerra de Irak. ${ }^{1}$ Esta constatación fue en gran medida la propulsora del Segundo Protocolo de la Convención de La Haya de 1999, un instrumento que concreta algunos de los deberes establecidos en términos más generales en la Convención de $1954 .^{2}$

Los atentados más recientes al patrimonio cultural han tenido lugar décadas después de que en la comunidad internacional se hubiera asentado la idea de que es necesario proteger estos bienes y observar una especial cautela en tiempos de guerra. Tanto en la antigua Yugoslavia como en Irak, se comprueba que el ataque a los bienes culturales y el consiguiente expolio y diseminación de los objetos no es imputable al desconocimiento por parte de las naciones enfrentadas de estas pautas de salvaguardia que hoy constituyen derecho internacional consuetudinario, hayan los estados implicados en la contienda ratificado o no estos instrumentos. ${ }^{3} \mathrm{Al}$ contrario, el origen de estos actos de destrucción y apropiación se fundamenta en los mismos motivos que tradicionalmente han sustentado estas prácticas. Son un comportamiento primario basado en la regla del más fuerte y la dominación sobre lo ajeno que se expande ante la ausencia de consecuencias criminales, jurídicas o morales.

Más recientemente, los movimientos yihadistas han puesto en jaque a la comunidad internacional, que ha sido incapaz de refrenar actos de destrucción sistemática. Poco valen a este respecto los aprendizajes del pasado. Los ataques al patrimonio parecen perseguir los mismos fines que en los conflictos más antiguos: desmoralizar al contrincante, destruir sus símbolos colectivos, minar su identidad, y destruir

1. Fernández Liesa (2009: 243 y ss.).

2. Henckaerts (1999: 28 y ss.).

3. Con una tesis políticamente poco correcta, O’Connell ha analizado el contexto político y de inteligencia militar en el que se diseñó la operación de ataque y ocupación iraquí por los Estados Unidos. En este trabajo, la autora explica que hubo una negligente omisión de determinados deberes ya consolidados en las prácticas bélicas, como la obligación de velar por la protección de los bienes culturales, en gran medida causada por las prioridades político-militares del momento, la escasa planificación del operativo con una subestimación de la capacidad de ofensiva del adversario, así como una parca dotación de los efectivos implicados en la misión. Este conjunto de circunstancias hizo prácticamente imposible cumplir con estos cometidos al tener que priorizar otros objetivos militares destacados, entre los que no constaba la salvaguardia del patrimonio cultural iraquí. "The decision to invade 'on the cheap' violated America's international law obligations on the conduct of war". Véase O'Connell (2004). 
sus fundamentos sociales e ideológicos. Con el transcurso de los años y la sofisticación de las relaciones internacionales, surgen nuevos usos asociados a estas conductas. Por este motivo, el ataque al patrimonio cultural comienza a vincularse con otras acciones delictivas de las que es posible extraer un beneficio económico, lo que se suma al ya consabido ataque ideológico y derrota del enemigo. La apropiación y el saqueo se convierten en una fuente de ingresos de los que sacar partido, de tal manera que las acciones bélicas despliegan un entramado de actividades estratégicas centradas, por una parte, en el cumplimiento de los objetivos marcados para el avance de la contienda y, por otra, en la obtención de recursos energéticos, armamentísticos y económicos. ${ }^{4}$ En relación con este último punto, los bienes culturales parecen haberse convertido en una vía de financiación para los grupos terroristas. Estas prácticas suponen un cambio de paradigma y la aparición de una conducta sistemática en el aprovechamiento de las riquezas culturales, lo que implica la dedicación de recursos humanos y logísticos a la creación y mantenimiento de redes de comercialización. Como tal, estas acciones se integran en el modus operandi de estos colectivos armados dando lugar a una situación sin precedentes que ha paralizado a la comunidad internacional, pues, si bien no es nuevo que el expolio esté asociado a la actividad terrorista, lo que sí constituye una novedad es su transformación en un proceso mecánico y a escala industrial. La sistematicidad con la que se incorporan estas actividades al curso ordinario de la planificación terrorista ha dado lugar a la que se considera la mayor destrucción de patrimonio cultural desde la Segunda Guerra Mundial. ${ }^{5}$ Pero debemos analizar en detalle la información disponible al respecto y entender las implicaciones de dichas conductas.

Desde 2014 varios medios de comunicación mencionaban el tráfico ilícito de objetos arqueológicos entre las primeras formas de financiación del grupo yihadista. ${ }^{6}$ Miembros de los cuerpos de inteligencia estadounidenses explican que el aumento del expolio es inversamente proporcional a la disminución del beneficio obtenido del comercio de petróleo. Asimismo, apuntan que las vías de comercialización son muy diversas, y académicos como Michael Danti, de la American School of Oriental Research, señalan que los expoliadores obtienen las piezas de numerosos

4. Blannin (2017: 13) nos recuerda que en el siglo xxi las nuevas redes terroristas han difuminado la línea que separaba los crímenes de terrorismo de los delitos convencionales, hasta llegar a fusionarse en numerosas oportunidades. Este parece ser el caso en la estructura y operativa de DAESH.

5. "ISIS' looting of the Middle East is 'the largest-scale mass destruction of cultural heritage since' WWII", publicado en Business Insider por Pamela Engel el 12/01/2016.

6. El comercio de antigüedades sería, tras el petróleo y los impuestos, la tercera fuente de financiación del grupo. Vid. "ISIS diversifica sus fuentes de ingresos para superar la dependencia del crudo" publicado en eldiario.es el 12/12/2015. Por su parte, el artículo de Duncan Mavin, publicado el 11/02/2015 en The Wall Street Journal, "Calculating the Revenue From Antiquities to Islamic State" recogía la opinión de las unidades de inteligencia occidentales que situaban el tráfico de antigüedades como la segunda fuente de financiación de DAESH, por detrás del petróleo. lugares, incluyendo museos, bibliotecas, archivos, colecciones privadas y, por supuesto, yacimientos arqueológicos ya explorados o excavados por ellos mismos. ${ }^{7}$ Todas estas noticias plantean más incógnitas que respuestas. Resulta complejo determinar cuál es el verdadero impacto de estas prácticas tanto por el número de piezas expoliadas como por la valoración del beneficio económico obtenido de su comercialización, datos que darían noticia de la verdadera repercusión de este atentado contra el patrimonio. Y no solo eso, resulta también difícil esclarecer el grado de implicación directa de la organización en estas actividades, lo cual serviría para demostrar que constituyen, en efecto, una fuente de financiación estable y bien articulada.

Como informaba la ONU, a mediados de 2016 había 4.500 recintos arqueológicos bajo el control de DAESH, de los cuales nueve habían sido declarados Patrimonio Mundial por la UNESCO. En aquel momento se estimaba que unos 100.000 objetos culturales estaban a su disposición, y que el grupo obtenía entre 150 y 200 millones de dólares anuales de su comercialización. ${ }^{8}$ Desde que las primeras estimaciones sobre cifras de beneficio comenzaron a publicarse en 2013 (Brennan y Fitz Gibbon 2017: 4), los titulares se han llenado de datos impactantes acerca del lucrativo negocio del comercio ilegal de antigüedades mantenido por DAESH. Sin embargo, los importes no son claros ni pueden contrastarse. Estos datos suelen replicarse o incluso magnificarse sin indicar una fuente fiable para el origen de la información. Esta incertidumbre dificulta los esfuerzos para establecer una vinculación directa entre el tráfico ilícito de antigüedades y la financiación de la organización.

En un deseo por ofrecer datos objetivos, un informe de la Comisión de Comercio Internacional de los Estados Unidos reveló que entre 2012 y 2013, cuando DAESH comenzó su expansión, la importación declarada de antigüedades a los Estados Unidos procedentes de Irak aumentó un $672 \%$ y la de Siria, un $133 \%$ (ver tabla 1 ).

Estos porcentajes parecen apoyar la idea de que existe una correlación entre una mayor presencia en el mercado de piezas procedentes de los territorios ocupados y el avance de la organización terrorista. No obstante, es prudente plantearse hasta qué punto este aumento en la circulación de antigüedades puede deberse a la situación de inestabilidad político-administrativa en la zona, convenientemente aprovechada por las redes de contrabandistas que ya actuaban desde antes, o es directamente imputable a una actividad orquestada por DAESH para comerciar con estos objetos.

Conviene no olvidar que esta región del mundo ha sido blanco del expolio durante décadas. La abundancia de yacimientos sumada a la sucesión de conflictos

7. Referencias tomadas de "How ISIS turns artifacts into cash", reportaje de Drew Griffin para la CNN publicado el $11 / 12 / 2015$

8. "ISIS is making $\$ 200$ million from stolen ancient artifacts", publicado en Business Insider el 06/04/2016.

9. "Conflict and the Heritage Trade: Rise in U.S. Imports of Middle East 'Antiques' and 'Collectors' Pieces' Raises Questions", publicado en Cultural Heritage Lawyer el 06/10/2014. 


\begin{tabular}{|l|c|c|c|c|}
\hline \multicolumn{5}{|c|}{ HTS - 9706: ANTIGÜEDADES DE MÁS DE 100 AÑOS } \\
\cline { 2 - 4 } País & 2011 & 2012 & 2013 & Cambio en \% \\
& \multicolumn{3}{|c|}{ en dólares actuales } \\
\hline Turquía & 15.979 .030 & 17.553 .638 & 19.257 .308 & $9,7 \%$ \\
\hline Egipto & 16.793 .409 & 13.817 .236 & 19.043 .410 & $37,8 \%$ \\
\hline Siria & 4.141 .235 & 4.714 .962 & 11.000 .869 & $133,3 \%$ \\
\hline Irak & 2.832 .384 & 585.682 & 4.523 .126 & $672,3 \%$ \\
\hline Líbano & 708.461 & 1.392 .005 & 2.218 .073 & $59,3 \%$ \\
\hline
\end{tabular}

Tabla 1.

en la zona, y un ambiente de inestabilidad política mantenido largo tiempo, han propiciado el establecimiento de redes de contrabando de antigüedades que se abastecen de las riquezas que aún esconde el territorio. El funcionamiento de estas organizaciones y el mantenimiento de flujos de circulación de objetos arqueológicos no surgen de la noche a la mañana. Por este mismo motivo, es difícil determinar qué porcentaje de esta actividad puede ubicarse en el marco de actuación de DAESH y qué proporción es imputable a las tramas de saqueadores ya establecidas que han aprovechado la coyuntura y el desorden derivado de la expansión del grupo terrorista para alimentar el mercado negro de bienes culturales de manera masiva.

A este respecto, numerosos grupos de investigación centrados en la protección del patrimonio cultural y la detección del expolio han incorporado como técnica de estudio el análisis de las imágenes por satélite de zonas sensibles. Una observación de los movimientos advertidos en el terreno en un marco cronológico determinado puede dar pistas sobre posibles actividades ilícitas en el lugar. Este método está siendo usado ampliamente en varios países, especialmente en aquellos que históricamente se han visto más afectados por estas prácticas. Por lo que respecta a las áreas de expansión de DAESH, el equipo de investigación de ASOR's Syrian Heritage Initiative ha liderado un proyecto centrado en el análisis de imágenes por satélite de Siria, norte de Irak, sur de Turquía y norte de Líbano desde 2010 a 2017 para determinar el impacto del expolio que se puede detectar sobre el terreno. ${ }^{10}$

Entre las conclusiones del proyecto, debemos destacar algunos puntos relevantes. En primer lugar, las actividades de excavación en entornos donde hay yacimientos arqueológicos se detectan tanto con anterioridad al conflicto como con posterioridad. Dado que las imágenes por satélite no pueden ofrecer datos sobre los objetos extraídos, las valoraciones se han

10. Véase Casana (2015), Casana y Laugier (2017) y Danti, Branting y Penacho (2017). El proyecto no solo trata de registrar posibles actos de expolio, sino también otras formas de ataque al patrimonio, como la ocupación de los yacimientos por unidades militares o la aparición de construcciones de diversos usos en zonas arqueológicas. Otras iniciativas similares han analizado también la evolución de las imágenes por satélite en la región, si bien centrándose en enclaves específicos y yacimientos ampliamente conocidos, lo que arroja un alcance inferior en estos estudios (vid. "AAAS Analysis Shows Widespread Looting and Damage to Historical Sites in Syria" publicado el 17/12/2014). tomado sobre el recuento de agujeros realizados clasificando la densidad de la actividad entre leve, moderada y severa. Así, si bien queda claro que el saqueo no es una práctica novedosa en la región, sí se advierte un aumento de la intensidad en el período 2014-2015, lo que, en términos comparativos con los períodos precedentes, más dilatados en el tiempo, supone un notable incremento del expolio. ${ }^{11}$ Por otro lado, los datos ponen de manifiesto que la distribución de las excavaciones es desigual en el territorio estudiado, tanto en zonas ocupadas por DAESH como en zonas no ocupadas. En términos generales, se advierte una mayor intensidad en estas prácticas en Siria en relación con el resto de áreas analizadas. En el país presenta la mayor concentración de excavaciones ilícitas, de las que el $50 \%$ se sitúan en zonas que nunca estuvieron ocupadas por DAESH, sino bajo el control de la oposición o del ejército sirio. Esto contrasta con la casi total ausencia de expolio en el norte de Irak, a pesar de estar bajo el control del grupo, algo que aún llama más la atención si se compara con lo sucedido en el sur del país durante la ocupación estadounidense, donde los ratios de saqueo alcanzaron niveles preocupantes (Casana y Laugier 2017: 12).

Así pues, si bien resulta evidente la conexión de la actividad expoliadora con la situación de inestabilidad política y de posterior conflicto armado, no es fácil imputar en exclusividad el auge del saqueo en este período a la actividad de DAESH. Este fenómeno puede deberse a otros factores que concurren en el lugar, no directamente conectados a la operativa desplegada por el grupo terrorista, y también parece apuntar a que, en gran medida, se trata de una práctica local (Casana y Laugier 2017: 22). La legislación siria establece que la excavación no autorizada de lugares arqueológicos es ilegal, de modo que la proliferación de estas prácticas en un momento en que la autoridad administrativa ha decaído, parece apuntar a la falta de estructura para perseguir estos delitos como otra causa del fenómeno, antes incluso de que DAESH hubiese ocupado estas zonas. A esto se suma la situación de extrema necesidad de la po-

11. Sobre la consideración de que es posible que en Siria existan alrededor de 15.000 yacimientos arqueológicos, el estudio estima, a la luz de las imágenes analizadas, que unos 3.000 han sido saqueados durante el período de conflicto, si bien no se trata de excavaciones completamente nuevas, ya que muchos de estos sitios habían sido objeto de excavaciones ilegales con anterioridad (Casana 2015: 147). 
blación, privada de los recursos más básicos para la subsistencia, que podían ver en el saqueo de bienes culturales un salvoconducto o una moneda de cambio para obtener alimentos y refugio (Casana 2015: 147).

De acuerdo con el estudio, en el último cuarto de 2014, este expolio indiscriminado en Siria comienza a decrecer, después de un aumento progresivo desde 2011 (Casana y Laugier 2017: 14). Entre 2014 y 2016 el saqueo disminuye, a excepción de las excavaciones ubicadas en los yacimientos más conocidos, que siguen registrando altos índices de actividad.

Conviene, por tanto, analizar con detenimiento la información disponible sobre la actividad de DAESH en cuanto al expolio de bienes culturales y tratar de discernir los hechos ciertos de aquellos otros que los medios le imputan por razones sensacionalistas o de conveniencia político-internacional. De hecho, los estudios citados se muestran escépticos a la hora de corroborar la tan expandida idea de que el grupo terrorista es el único responsable del expolio masivo de las zonas en conflicto. La constatación sobre el terreno de que estas excavaciones indiscriminadas tienen lugar tanto en zonas ocupadas como en zonas no ocupadas no ayuda a respaldar esta teoría. Existen otros argumentos de apoyo en relación con la estructura administrativa de DAESH y su forma de financiación que pasaremos a analizar a continuación. No obstante, lo que sí es evidente es la íntima relación que existe entre la situación de inestabilidad político-administrativa con el auge de estas prácticas. Todo conflicto lleva aparejada una gran amenaza para el patrimonio cultural.

\section{El tráfico ilícito de bienes culturales como forma de crimen organizado: modus operandi y medio de financiación}

Es difícil olvidar las imágenes de la destrucción de ciudades declaradas Patrimonio Mundial de la Humanidad por la UNESCO como Palmira, Hatra, Nínive, Nimrod o Tombuctú, enclaves irremplazables para la cultura mundial. En la estrategia diseñada por DAESH, estos actos servían a sus fines propagandísticos para obtener atención internacional; pero también a sus objetivos político-religiosos de luchar contra la idolatría y atacar los símbolos identitarios de los colectivos enemigos. Se trata de una ideología de fuerte fundamento religioso que apelaba a la fe para sustentar su movimiento y a la guerra santa para justificar la violencia, si bien debe tenerse presente que el objetivo del grupo es tomar el control de los territorios ocupados y formar un gobierno.

Precisamente, dentro de la campaña de difusión llevada a cabo por el grupo, se hizo un uso intencional de los vídeos que registraban estos ataques a monumentos. Estas grabaciones dieron la vuelta al mundo y con ellas se despertó el interés de la comunidad internacional. Al mismo tiempo, se ponía nuevamente de manifiesto la vulnerabilidad del patrimonio, dejado a merced del vandalismo y el extremismo más radicales. Poco consuelo supone saber que algunos de estos actos fueron auténticas puestas en escena en las que se filmaba la destrucción de réplicas, ${ }^{12}$ pero la demolición de muchos enclaves de una riqueza cultural incomparable ha sido real.

Paralelamente a estos espectáculos de destrucción, DAESH parecía poner en marcha todo un sistema para institucionalizar el expolio de bienes culturales y obtener de ello un rendimiento económico. La estructura debía funcionar para evitar la fuga de recursos y mantener el control de los ingresos, además de instaurar mecanismos de supervisión y seguimiento de la actividad de los saqueadores, lo que servía al mismo tiempo como forma de ejercicio de la autoridad y dominación de la población.

\section{Modus operandi: estructura $y$ funcionamiento de las redes de tráfico ilícito de antigüedades}

Gran parte de los datos disponibles sobre el funcionamiento de DAESH en relación con el tratamiento y gestión de las antigüedades proviene de la documentación requisada tras una operación llevada a cabo por las fuerzas armadas de Estados Unidos en mayo de 2015 al este de Siria. Esta misión concluyó con la muerte de Abu Sayyaf, un oficial de alto rango dentro de la organización a quien se había encomendado la dirección del Diwan al-Rikaz (Ministerio de Recursos Naturales), lo que incluía el control del petróleo, del gas y de otros recursos, como las antigüedades. En el registro del local se identificaron más de 500 piezas arqueológicas, además de abundante documentación que permitió a las unidades de inteligencia comprender el sistema de financiación del grupo y el papel que en todo esto jugaban los bienes culturales. Tras el hallazgo de estos archivos, las noticias sobre el expolio masivo de antigüedades y su aprovechamiento para obtener beneficios se extendieron rápidamente, si bien seguía habiendo dudas sobre el alcance de estas prácticas y el volumen de beneficios que realmente reportaban a la organización.

A pesar de las circunstancias adversas para restablecer un pseudogobierno en los territorios ocupados a medida que DAESH continuaba su expansión, el grupo hizo esfuerzos por recuperar el control administrativo y asumir la dirección de las instituciones. Entre las primeras medidas estaban las de reorganizar la estructura de gobierno y garantizar la sostenibilidad económica. Los documentos hallados en la redada de 2015 daban cuenta de la creación de un Ministerio de Recursos Naturales, encargado de los recursos del suelo y subsuelo, entre ellos petróleo, gas y riquezas arqueológicas. Dependiente de este ministerio estaba la División de Antigüedades, responsable de controlar y gestionar los bienes culturales. Esta división

12. Algunas de las piezas destruidas que se ven en los vídeos distribuidos por DAESH pertenecientes al Museo de Mosul habían sido trasladadas a finales de 2014 por las autoridades a cargo de la institución y reemplazadas por réplicas. Otras, en cambio, sí eran originales. “'Ancient statues' destroyed by ISIS in Mosul were FAKES - and the originals are safely stored in Baghdad, claims Iraqi museum director" en Daily Mail 16/03/2015, y "ISIS devastated Mosul Museum, or did it?", en CNN, $17 / 03 / 2017$. 
supervisaba los yacimientos, concedía licencias de excavación y autorizaba la salida de esos bienes de los territorios ocupados. Solo quienes contasen con una autorización emitida por esta división podían excavar, extraer y trasladar los tesoros hallados. ${ }^{13}$

Asimismo, la documentación requisada daba cuenta del mecanismo diseñado para obtener beneficios de las antigüedades por tres vías: un sistema de impuestos, la concesión de licencias de excavación y la venta directa de piezas. El hallazgo de recibos y permisos de excavación proporcionaba información de enorme valor para conocer la estructura de la organización y hacerla responsable de un expolio sin precedentes en la zona. Estos archivos supusieron para muchos investigadores y periodistas, que desde hacía meses venían alertando de la vinculación del grupo con el saqueo en la zona, una prueba irrefutable de dicha conexión. ${ }^{14}$ A pesar de las dificultades para ofrecer cifras ciertas del valor real del expolio, los expedientes y papeles incautados hablaban de una estructura administrativa aparentemente creada para institucionalizar el comercio ilegal de bienes culturales y convertirlos en una fuente de financiación. Con ello, DAESH quedaba identificado como principal artífice de los ataques indiscriminados al patrimonio y se situaba en el punto de mira de la operativa internacional de lucha contra el terrorismo, considerándolo autor y responsable del tráfico ilícito de bienes arqueológicos procedentes de la región, aun cuando no se hubiese demostrado su participación directa. ${ }^{15}$

No obstante, es conveniente analizar estos datos con prudencia y estudiar más en detalle la naturaleza de esta actividad; no olvidemos que, de acuerdo con las imágenes por satélite ya mencionadas, el expolio en Siria se distribuye en todo el territorio de manera desigual, tanto en zonas ocupadas como en otras que no al $50 \%$, y que en otras áreas controladas, como al norte de Irak, los enclaves arqueológicos no se han visto más afectados de lo que ya sucedía antes de que estallara el conflicto. Esta situación se suma a unas prácticas mantenidas largo tiempo, muy anteriores al contexto bélico actual. Oriente Medio es una de las regiones del mundo más afectadas por un

13. Para información en detalle sobre esta documentación y su traducción al inglés, véase el informe de Andrew Keller "Documenting ISIL's Antiquities Trafficking: The Looting and Destruction of Iraqi and Syrian Cultural Heritage: What We Know and What Can Be Done" (disponible en <https://2009-2017. state.gov/e/eb/rls/rm/2015/247610.htm>).

14. Las referencias en los medios respecto a esta operación de 2015 son numerosísimas. Casi todos los periódicos que se hicieron eco de la noticia anunciaban en sus titulares la vinculación de DAESH con el expolio masivo de la zona. También así Howard, Elliott y Prohov (2016: 2).

15. Casana y Laugier (2017: 12) señalan varios ejemplos en que los medios han alimentado la idea de que DAESH estaba detrás de varias operaciones de tráfico ilícito de antigüedades destapadas recientemente. Apuntan al conocido caso Hobby Lobby, empresa que adquirió e introdujo ilegalmente en Estados Unidos más de 3.450 tablillas cuneiformes. El caso se desveló en 2011, pero las autoras explican que esas tablillas provienen del sur de Irak y que muy probablemente procedían de un expolio ocurrido años antes del comienzo de la guerra en Siria. Lo mismo puede decirse de unos mosaicos extraídos de Apamea, zona que estaba bajo el control de la milicia siria, no de DAESH. expolio endémico de su propia población que, acuciada por la situación de inestabilidad y la abundancia de yacimientos, han alimentado el mercado negro de antigüedades desde décadas atrás. ${ }^{16}$

Así pues, el conjunto de factores parece apuntar a que el grupo terrorista ha aprovechado unas prácticas ya instauradas en el lugar y las ha incorporado a su sistema funcional, con mayor o menor aprovechamiento. La diversificación de los recursos y la sofisticación de la organización, con una estructura sólida y una logística bien diseñada, ha permitido a DAESH ser una organización criminal autosuficiente y conquistar territorios rápidamente.

Una de las principales características del crimen organizado del siglo xxi es la generación de tramas delictivas en donde distintos tipos de conductas se entrelazan para servir a un mismo fin de expansión y control. En el caso que nos ocupa, la búsqueda de formas de financiación alternativas a las tradicionales hace que las operativas de lucha contra el terrorismo vean mermada su eficacia al no poder cortar de raíz sus fuentes de ingresos, que es una de las maneras más eficaces de sofocar los alzamientos de este tipo (Howard, Elliott y Prohov 2016: 15). En el crimen organizado moderno se produce una superposición de delitos en círculos de actividad que implican a distintos actores y en los que el tráfico de drogas, de armas o de antigüedades pierden sus contornos habituales para entremezclarse, ya que algunos de estos activos pueden emplearse como monedas de cambio por el otro. De este modo, la criminalidad alcanza un alto grado de sofisticación que se aprovecha de los canales de distribución preexistentes y de los delincuentes involucrados con anterioridad en esas redes para introducir nuevos productos con los que traficar, incorporándose a la lista más recientemente los bienes culturales. ${ }^{17}$ Los métodos habituales, basados en la extorsión, los secuestros o el robo son solo reminiscencias de un tiempo anterior. Hoy hay que tener muy en cuenta el componente tecnológico y el uso de técnicas modernas que son, la mayoría de las veces, mucho más rápidas y productivas (Shelley 2014: 188 y ss.; Blannin 2017: 14).

No parece haber demasiadas dudas de que DAESH es una organización criminal que ha diversificado su

16. Véase Howard, Elliott y Prohov (2015: 16, 2016: 26), Casana (2015: 147). Un periodista de la ARD, German Public Broadcaster, especialista de Oriente Medio, declaró en una entrevista realizada el 15 de febrero de 2015: "if you ask people from Syria, they would simply answer: everyone is trafficking antiquities. And, by the way, they have been doing this for decades, it just increased now dramatically, because of the political chaos" [si preguntas a gente de Siria, simplemente responderán: todo el mundo trafica con antigüedades. Y, por cierto, llevan haciendo esto décadas, simplemente se ha incrementado ahora dramáticamente debido al caos político -t.p.--] (Howard, Elliott y Prohov 2015: 15, entrevista con los autores).

17. Entre otros: Howard, Elliott y Prohov (2016: 15), Shelley (2014: 261-262), Campbell (2013: 114), Dietzler (2013: 329). Se ha señalado que DAESH comerciaba con antigüedades para obtener armas. En otoño de 2016 se llevó a cabo una operación contra la mafia italiana, acusada de vender armas a DAESH a cambio de antigüedades, transportándolas directamente a Italia desde la costa libia (vid. "Arte antica in cambio di armi, affari d'oro in Italia per l'asse fra Isis e 'ndrangheta", publicado en La Stampa el 16/10/2016). 
campo de acción y ha incorporado nuevas conductas delictivas a su estrategia de expansión. ${ }^{18} \mathrm{Su}$ modus operandi encaja con la tendencia observada en otras organizaciones criminales en el nuevo milenio, al establecer una fuerte estructura centralizada que permite mantener la dirección del grupo y, simultáneamente, desplegar una intrincada red de actores implicados en distintas acciones claves para su operativa. DAESH ha combinado en todo momento una política propagandística con uso de las nuevas tecnologías que le ha permitido captar adeptos incluso en el mundo occidental, con el establecimiento en los territorios ocupados de una suerte de pseudogobierno bien organizado.

Pero conviene preguntarse el grado de responsabilidad que el grupo tiene sobre el expolio de antigüedades observado en la región o plantearnos si, más bien, ha sabido absorber las redes preexistentes e introducirse en ellas a la cabeza del escalafón para controlar la mercantilización de esos bienes y participar directamente de los beneficios. Esta idea podría apoyarse en que el saqueo y comercio ilegal de antigüedades es una práctica largamente asentada en la zona, que ha sobrevivido a los sucesivos conflictos y se ha mantenido con independencia de cuál fuese el grupo que gobernaba la región en cada momento. Asimismo, otros ejemplos históricos de redes dedicadas al contrabando de bienes culturales han permitido trazar su estructura de funcionamiento, desarrollado a través de organizaciones descentralizadas y poco jerarquizadas compuestas por individuos en distintos niveles de actividad que muchas veces se implican por razones de conveniencia y oportunidad.

Estudios recientes sobre el funcionamiento y composición de las redes dedicadas al tráfico de antigüedades arrojan algo de luz a este respecto. Campbell ha partido del análisis de otros casos ya resueltos para identificar pautas comunes que parecen caracterizar este tipo de actividad delictiva. Así, tras indagar en los casos Medici y Lydian Hoard, y analizar lo sucedido en Irak, Afganistán y Bulgaria con otras redes desarticuladas más recientemente, llega a la conclusión de que el tráfico ilícito de bienes culturales se sustenta en redes poco jerarquizadas formadas por personas cuyo grado de implicación en las acciones de aprovisionamiento, transporte y comercialización es variable y se produce por razones de oportunidad y capacidad de cada individuo. De esta manera se generan flujos de abastecimiento y venta que funcionan de modo independiente, y cuyos actores son fáciles de sustituir o tienen roles intercambiables, especialmente en los niveles más bajos de la estructura. Esto se demuestra por el hecho de que, incluso después de haber procesado y condenado a los cabecillas de la operación Medici, la trama de contrabando siguió funcionando de manera autónoma (Campbell 2013: 118). A continuación, el autor se centró en casos de tráfico ilícito vinculados a zonas de conflicto como Irak y Afganistán para llegar a la misma conclusión sobre la pauta de comportamiento.

18. Respecto a las distintas nociones sobre qué es una organización criminal y en qué grado pueden estar implicadas en el tráfico ilícito de antigüedades como nueva práctica delictiva, véase Dietzler (2013: 334).
El estudio permite extraer un esquema de funcionamiento dividido en cuatro fases principales: el saqueo, el transporte, el blanqueo y la venta (Campbell 2013: 116). La participación de los individuos implicados en cada fase requiere un distinto nivel de conocimiento y especialidad. Muchas veces en la fase de excavación, se encuentran habitantes de las localidades donde se ubican los yacimientos, que conocen bien el terreno y la situación; pero no necesitan dominar las rutas de distribución o determinar la mayor o menor importancia de los objetos extraídos. A continuación, vienen los transportistas, responsables del traslado de las piezas y el cruce de fronteras, que tampoco han de tener conocimientos especializados sobre los bienes. Estos conocimientos sí se requieren, en cambio, en las personas que intervienen en los últimos tramos de la cadena de distribución, para tasar las piezas y concretar su valor, crear un rastro de documentación falsa que legitime su comercialización, o asesorar a compradores y coleccionistas sobre la procedencia y la exclusividad de los objetos.

Una visión en conjunto de este esquema de funcionamiento permite advertir que el tráfico ilícito de antigüedades aparece asociado a otras conductas delictivas, como la falsedad documental, el contrabando, la prevaricación o el fraude; y que los individuos involucrados en este proceso cuentan con distintos grados de conocimiento, siendo más cualificado en las últimas fases que en las iniciales. De hecho, quienes participan en los procesos de excavación suelen ser lugareños que ven en estas actividades una oportunidad de mejorar su precaria realidad, es decir, la conjunción de oportunidad y circunstancias suele decantar su entrada en las redes; pero su intervención no es exclusiva, ya que estos primeros peones de la cadena pueden ser sustituidos por cualquier otro individuo en igual situación de necesidad. La doctrina señala que para que surja una estructura criminal organizada deben concurrir tres factores: un objetivo apropiado, un grupo motivado y la ausencia de capacidad de control, ya sea por un contexto de inestabilidad como por falta de cohesión social suficiente. ${ }^{19}$ A la vista de los acontecimientos, resulta evidente que la región de Oriente Medio ha sido, desde el comienzo del conflicto en 2011, el caldo de cultivo idóneo para la expansión de estas prácticas que han seguido un cronograma de manual en lo que al tráfico de antigüedades se refiere..$^{20}$

Debemos, entonces, centrarnos en los datos disponibles para analizar el funcionamiento de DAESH y el tratamiento que hacían de los bienes culturales para discernir el papel que desempeñan en el tráfico ilícito de la región.

19. Véase Dietzler (2013: 336) y los autores que cita.

20. Al poco de estallar el conflicto, el ministro de cultura y finanzas de Siria junto con el gobernador del Banco Central Sirio alertaron el 7 de julio de 2011 sobre la necesidad de tomar medidas de salvaguardia del patrimonio cultural del país, ante el riesgo inminente de expolio (Ali 2013: 352; Howard, Elliott y Prohov 2015: 15). Pero la alerta fue claramente insuficiente: un mes más tarde se daba aviso de que una estatuilla aramea de bronce del siglo vIII a. C. había sido robada del Museo Arqueológico de Hama (Ali 2013: 353). 


\section{Redes de distribución y cadenas de intermediarios}

The Wall Street Journal publicó el 6 de agosto de 2017 la entrevista realizada a Mr. Al-Hassan y Omar Al-Jumaa, dos marchantes de arte sirios, en la que desvelaban la forma de proceder de DAESH en el expolio de antigüedades. De acuerdo con su testimonio, el grupo coaccionaba a individuos con algunos conocimientos sobre arqueología e historia, capacitados para localizar las piezas dentro de los yacimientos y elaborar informes sobre sus características. La propia estructura ministerial del Diwan al-Rikaz parecía estar concebida para engrasar esta maquinaria, de forma que se otorgaba a los lugareños autorizaciones oficiales para que excavasen los sitios en busca de tesoros. Inicialmente, las licencias eran gratuitas, a cambio de fidelidad al grupo y el pago de un $20 \%$ de lo obtenido con su comercialización. Más tarde esta práctica cambió, de modo que se obligaba a los extractores a vender las piezas a DAESH con un $20 \%$ de descuento sobre su valor estimado, y luego el grupo se encargaba de revenderlas. A continuación, una red de intermediarios compraba las piezas a DAESH y las comercializaba fuera de Siria e Irak, en muchas ocasiones camufladas en convoyes de ayuda humanitaria, en transportes de mercancías exportadas o incluso siendo transportadas a escondidas por mujeres, a quienes rara vez registran por razones de moralidad religiosa. Después, esos intermediarios vendían los objetos a marchantes como Mr. Al-Hassan o Al-Jumaa, que se encargaban de introducirlos en el mercado occidental, buscando particularmente a cada comprador. Según sus propias declaraciones, el negocio va bien, y siempre hay algún marchante dispuesto a adquirir una pieza para un cliente, y no hay diferencias: los objetos acaban en Moscú o Londres. ${ }^{21}$

Según las declaraciones de estos contrabandistas y marchantes entrevistados, el objetivo es localizar piezas pequeñas de alto valor. Cuanto menores sean las dimensiones, más fáciles de trasladar y hacer el cruce de fronteras. Por este motivo, los objetos más codiciados son joyas y monedas, para lo que los saqueadores se suelen valer de detectores de metales, además de pequeñas estatuas, piedras talladas o cabezas esculpidas. A esto se suma una modernización de las técnicas de comercio, que se aprovechan también del anonimato y rapidez que proporciona internet. Como difunden algunos medios de comunicación, han llegado a ofrecerse piezas robadas en plataformas como eBay o Facebook. ${ }^{22}$

Este relato coincide con el testimonio de otro hombre intermedio, Mohammed, entrevistado por Simon Cox, de la BBC, el 17 de febrero de 2015, quien describe la cadena de distribución de antigüedades en términos muy similares. Este marchante

21. "The Men Who Trade ISIS Loot" publicado en The Wall Street Journal el 06/08/2017.

22. "Antiquities looted by Islamic State turn up on eBay" publicado en The Times el 14/03/2015; "A la venta en Facebook: antigüedades robadas en Medio Oriente" publicado en The New York Times el 13/05/2019. aseguraba, además, que los ingresos eran cuantiosos y que DAESH se valía de los contactos que tenían en el extranjero para mercadear con las piezas, distribuyéndolas a través de comerciantes ubicados en países como Turquía donde la salida hacia Europa occidental es muy accesible. ${ }^{23}$

Estas y otras declaraciones de contrabandistas y marchantes entrevistados dan cuenta de un flujo de bienes culturales bien abastecido en el que DAESH jugaba un papel determinante. A esto se suman nuevas informaciones aportadas por analistas y académicos que conocen bien el terreno y estas prácticas heredadas. Así, Amr Al-Azm Markus, arqueólogo de origen libanés hoy establecido en Ohio, que había formado parte del departamento de antigüedades de la Universidad de Damasco hasta 2006, explica que el expolio es una costumbre muy arraigada en la región y que, si bien DAESH parece ser el responsable de la mayor parte de la pérdida del patrimonio cultural sirio, en realidad ningún bando tiene las manos limpias. AlAzm explica en una entrevista con Bryan Schatz en marzo de 2015 que estas redes funcionan con enormes cadenas de intermediarios que se van traspasando los objetos de forma sucesiva, ${ }^{24}$ y que puntualmente surge un "big fish", un marchante dispuesto a retener los bienes durante un tiempo largo a la espera de que se revaloricen y se pierda paulatinamente el rastro y el recuerdo de su posible vinculación con el expolio en la región. ${ }^{25}$ Sobre esta idea también han incidido otros autores, que apostillan además que las grandes piezas rara vez salen a la luz, ya que entran en el curso del mercado negro en operaciones que se negocian directamente con coleccionistas privados (Howard, Elliott y Prohov 2016: 10).

El conjunto de indicios que se han ido recopilando en estos años de análisis y operaciones demuestran la existencia de un expolio masivo en los peores años del conflicto, tanto en zonas bajo control del grupo como en otras no ocupadas. Cabe entonces preguntarse dónde está ese volumen enorme de bienes saqueados. La aparición de piezas sirias en el mercado legal de antigüedades está siendo discreta. Muchas veces se trata de pequeñas piezas que llaman menos la atención. ${ }^{26}$ La principal dificultad se presenta con el comercio de objetos procedentes de yacimientos sin

23. "The men who smuggle the loot that funds IS" publicado en BBC News el 17/02/2015.

24. Este mecanismo de cadena de traspasos se describe en detalle en el reportaje "Blood antiques", centrado especialmente en el tráfico ilícito de piezas procedentes de Afganistán. El reportaje se adentra en el entramado de mercado negro y relata cómo los lugareños excavan indiscriminadamente los enclaves arqueológicos para obtener piezas, y como entran en un curso de distribución bien articulado donde cada eslabón de la cadena poco o nada sabe de los intermediarios precedentes ni de los posteriores. Finalmente las piezas llegan a Europa, a manos de anticuarios poco escrupulosos que conocen a la perfección el origen ilícito de las piezas.

25. 'Meet the 'Monuments Men' Risking Everything to Save Syria's Ancient Treasures From ISIS", reportaje de Bryan Schatz publicado en Mother Jones el 06/03/2015.

26. Se detecta una mayor presencia de pequeñas piezas en los mercados de antigüedades locales de Jordania, Turquía y Líbano, además de Internet, especialmente con monedas. Vid. supra "ISIS diversifica sus fuentes de ingresos [...]" (eldiario. es). 
excavar, porque estos bienes están sin inventariar, sin identificar y sin certificar su procedencia legítima a la hora de introducirlos en el comercio internacional. Sobre esto, Casana y Laugier (2017: 26) señalan que, si bien no se puede saber qué objetos concretos se han desenterrado, el conocimiento de los puntos de extracción puede dar una idea de la naturaleza, estilo, época y tipo de piezas excavadas, lo cual puede ser útil para identificar el origen de las piezas cuando comiencen a aflorar en el mercado. No obstante, el número de objetos incautados actualmente no parece corresponder con el volumen supuestamente extraído, a la luz de la proliferación de excavaciones en la región. A este respecto, las valoraciones de los profesionales son dispares. A mediados de 2015 los marchantes de arte en Londres explicaban que el comercio de obras expoliadas aún no había salido a la superficie en los mercados occidentales, aunque sí se habían identificado algunas piezas aisladas cuyas características parecían apuntar a un origen muy turbio y poco claro procedente de los territorios ocupados. ${ }^{27}$

La ausencia de más incautaciones de piezas al intentar su comercialización, sumada a la estrategia empleada por algunos marchantes avezados que prefieren retenerlas para ver incrementado su valor, según cuentan arqueólogos experimentados, podría explicar esta falta de correspondencia en los números que cabría esperar. Asimismo, quizás una mayor sofisticación de los métodos de blanqueo o los sistemas de distribución de los objetos pudiera explicar estas divergencias. El Dr. Maamoun Abdulkarim, arqueólogo responsable del departamento sirio de antigüedades de Damasco, explica que en las rutas seguidas por los contrabandistas de antigüedades los destinos preferentes son Suiza, Alemania, Reino Unido y países del Golfo como Dubái y Qatar. Sin embargo, en los países citados, aún no ha sido nadie detenido en relación con estas redes de distribución. A este respecto, Vernon Rapley, actual jefe de seguridad del Victoria and Albert Museum en Londres, y anterior director de la Brigada de Arte y Antigüedades de Scotland Yard, señala que en muchas ocasiones las piezas son confiscadas a su entrada en Reino Unido, pero que es difícil contar con pruebas suficientes para presentar cargos criminales, por lo que los casos pasan inadvertidos para la prensa y para el público en general. Cuando esto sucede, la labor policial se concentra en investigar las piezas, tratar de identificarlas y custodiarlas para una futura restitución al país de origen. ${ }^{28}$

De acuerdo con numerosas fuentes periodísticas, las autoridades europeas y estadounidenses explican que las piezas se sacan del país a través de Turquía ${ }^{29}$ y Líbano, en la mayor parte de los casos. Se dice que se usan las mismas rutas de contrabando ya establecidas para otros bienes, por lo que no es solo DAESH quien obtiene beneficios de este mercadeo, sino también los rebeldes, la milicia kurda o el propio

27. "Save our stones", publicado en The Economist el 13/06/2015.

28. "Islamic State: Looting for Terror" es el reportaje de Simon Cox en File on 4 de la BBC Radio 4, emitido el 17 de febrero de 2015.

29. Vid. Cengiz (2017). régimen. ${ }^{30}$ Desde ahí, pasan a países de Europa del este, como Bulgaria y Rumanía, antes de lanzarlos a Europa occidental, a países como Alemania o Suiza. Asimismo, otra vía de comercialización cada vez más habitual es enviar las antigüedades a países asiáticos, Tailandia, Singapur, desde donde se importan a Europa con mayor facilidad debido a los acuerdos comerciales y la flexibilidad en la circulación de mercancías. Arthur Brand, investigador afincado en Ámsterdam que ha indagado en profundidad en el mercado negro de antigüedades, señala que los principales centros de comercialización se encuentran en los países citados, porque allí están los mayores coleccionistas de antigüedades, a los que recientemente se suman los nuevos ricos con capitales procedentes del petróleo, ubicados en Oriente Medio. ${ }^{31}$

Por lo tanto, parece que las piezas llegan a los países mencionados, pero muchas veces se pierde el rastro de su comercialización una vez que cruzan la frontera. Si en los pasos intermedios es relativamente fácil dar con un marchante de frontera en Turquía ${ }^{32}$ o Líbano ${ }^{33}$ que ofrezca los objetos sin demasiadas reticencias, en el momento en que los bienes entran en las plazas europeas, las exigencias derivadas de la reputación y la confianza profesional obligan a trabajar con mayor cautela.

Curiosamente, los compradores más tentados por este comercio son individuos con una historia personal vinculada de algún modo a los colectivos que DAESH trata de aniquilar y destruir y que residen en Estados Unidos y Europa occidental. ${ }^{34}$ Por su parte, en estudios previos en relación con otras redes de tráfico de antigüedades, la doctrina ha señalado que la mayor parte de los beneficios no recaen en los lugareños que ejecutan el saqueo, forzados, muchas veces, por su situación de necesidad, sino en los intermediarios, que les pagan una pequeña comisión. ${ }^{35}$

Esta constelación de datos e informaciones nos obliga a preguntarnos dónde ha ido a parar el ingente volumen de piezas expoliadas. ¿Son en su mayoría reservadas por los marchantes en espera de un mejor momento para su venta $y$, si es este el caso, sirven entonces para financiar el terrorismo? ¿Se están negociando operaciones particulares con coleccionistas privados $\mathrm{y}$, de ser así, en número suficiente para absorber la totalidad de las piezas que

30. "Inside the Underground Trade to Sell Off Syria's History" por Mike Giglio, publicado en BuzzFeed News el 30/07/2015 y "ISIS Is Selling Syria's Antiquities to the West" video de The Wall Street Journal publicado el 31/05/2017.

31. Vid. supra "Islamic State: Looting for Terror" (BBC Radio 4).

32. El periodista Mike Giglio declaró que se le ofrecieron en venta varias antigüedades mientras trabajaba en su reportaje "Inside the Underground Trade to Sell Off Syria's History" para BuzzFeed News.

33. Lo mismo le sucedió a Simon Cox mientras estaba en Líbano, grabando su reportaje "Islamic State: Looting for Terror", para la BBC Radio 4.

34. Vid. supra "The Men Who Trade ISIS Loot" (WSJ).

35. Véase Dietzler 2013: 330. La autora recoge también las conclusiones de un trabajo previo de Brodie, quien había llegado a apuntar que los peones de la cadena ingresaban apenas el $1 \%$ del beneficio, mientras que el $98 \%$ quedaba repartido en manos de los sucesivos intermediarios (Dietzler 2013: 331). 
se estiman en circulación? ¿Van los beneficios de estas ventas directamente al DAESH? ¿Cómo puede ser el comercio de antigüedades una forma efectiva y estable de financiación si las piezas no afloran en el mercado? ¿Existe una trama de mercado negro suficientemente amplia para asimilar todas las antigüedades? ¿No se está sensibilizando el mercado mundial con la necesidad de proteger el patrimonio cultural en momentos de conflicto?

\section{Recapitulación y valoraciones sobre el tráfico ilícito}

\section{Cifras de negocio}

Como ya señalamos anteriormente, existe un gran desconocimiento sobre la valoración de los supuestos beneficios que DAESH obtiene con estas prácticas, con estimaciones que van desde cantidades modestas a varios millones de dólares. ${ }^{36}$ Las incógnitas son múltiples. En primer lugar se desconoce el volumen de objetos expoliados, ya que las imágenes por satélite que muestran las numerosas excavaciones no dan cuenta de si en esas operaciones se localizaban objetos, ni, de ser así, cuántos son o de qué valor e importancia. Asimismo, resulta sorprendente la escasa aparición de piezas en el mercado, en una cantidad equivalente a las extracciones masivas que se denuncian, y por un valor que responda a las cifras anunciadas en los medios. Por todos estos motivos, conviene sopesar y analizar los datos disponibles con el criterio suficiente para no caer en el sensacionalismo ni en afirmaciones falaces.

Las estimaciones sobre la cifra de negocio proceden en gran medida de la documentación requisada durante la redada de Abu Sayyaf. Los recibos y libros de cuentas incautados daban noticia de la estructura económica del grupo y de sus beneficios procedentes de diversas fuentes, de donde 265.000\$ parecían proceder del negocio de las antigüedades. ${ }^{37}$ Asimismo, se parte de los datos obtenidos tras una operativa de los servicios de inteligencia iraquíes, que informan de que el grupo obtiene ingresos por valor de 36 millones de dólares solo con el comercio de antigüedades saqueadas en la ciudad de al-Nabuk. ${ }^{38}$

36. Bel Trew cita en su artículo "Antiquities experts call for war on Isis looting in Syria and Iraq" publicado en The Times el 12/08/2017 ingresos superiores a los 100 millones de dólares. Ver también “Countering is's theft and destruction of Mesopotamia”, reportaje de Mark V. Vlasic y Helga Turku publicado en World Policy el 07/07/2015 donde recopilan cifras publicadas en distintos medios, alguna declarando ingresos de 100 millones de dólares al año en el mercado negro. Numerosas referencias también en Brennan y Fitz Gibbon (2017: 3), Howard, Elliott y Prohov (2015: 14; 2016: 37).

37. Howard, Elliott y Prohov (2016: 37) explican que estos números se refieren a los impuestos recaudados en relación con las licencias de excavación y los porcentajes de comisión por las ventas de piezas arqueológicas. Sobre la base de esta recaudación, Keller (ver supra "Documenting ISIL's Antiquities Trafficking...”) explica que esto se correspondería con transacciones por valor de 1,25 millones de dólares únicamente con relación a la documentación requisada en la redada.

38. Blannin (2013: 16), Howard, Elliott y Prohov (2016: 37). El reportaje de Martin Chulov "How an arrest in Iraq revealed Isis's \$2 bn jihadist network" publicado en The Guardian el
A esto se suman las declaraciones de algunos expertos, que señalan el comercio con bienes culturales como segunda fuente de financiación de DAESH, por detrás del petróleo y el gas, como ya hemos visto.

No obstante, muchos autores se muestran escépticos con algunos de estos datos y ponen en duda el uso periodístico de estas cifras, ya que a veces los medios están llevados por impulsos políticos o sensacionalistas que pueden deturpar la realidad de los hechos. El propio Al-Azm, a quien ya hemos mencionado, encuentra estos datos poco verosímiles pues afirma que en algunos pequeños museos provinciales saqueados el valor de las piezas no alcanza de modo alguno esos importes. ${ }^{39}$ Asimismo, otros académicos han cuestionado el manejo de esta información y la credibilidad de estas cifras.

Con la información extraída de la documentación hallada en las distintas operaciones, sumada al testimonio de varios intermediarios entrevistados en distintos medios, se puede dibujar el siguiente esquema de obtención de recursos:

- Pago de tributos: en concepto de "Khums", el nombre dado al impuesto que aplican a los musulmanes sobre el valor monetario de cualquier objeto hallado en el terreno. Según Al-Azm, el porcentaje varía según la zona, entre un $20 \%$ en Alepo hasta un $50 \%$ en Al-Raqa, dejando el porcentaje a la discreción de la unidad de la zona. ${ }^{40}$ Keller informó de que en la documentación requisada en la redada el porcentaje era del $20 \%$.

- Ingresos por ventas: en la redada de Abu Sayyaf se hallaron 11 recibos de venta de objetos arqueológicos, entre el 6 de diciembre de 2014 y el 26 de marzo de 2015, firmados por la División de Antigüedades. Su importe ascendía a 265.000\$.

Al mismo tiempo, esta documentación pone de manifiesto que DAESH, a través de la División de Antigüedades del Diwan al-Rikaz, trataba de mantener bajo control la explotación de los recursos culturales. ${ }^{41}$ Así, para impedir las excavaciones realizadas sin supervisión, exigía que toda actividad de extracción fuese previamente autorizada a través de una licencia firmada y sellada por la División. El no tenerla implicaba una sanción. Al mismo tiempo, prohibía a cualquier otro mando de la organización que no formase parte de dicha División la emisión de permisos de excavación, y se anulaba cualquier otra autorización previa emitida por la anterior administración. Para Al-Azm, la exigencia de una licencia y el control de la actividad era una forma de institucionalizar unas

15/06/2014 da cuenta de esta operación de la inteligencia iraquí y detalla las cantidades incautadas y de que se ha comerciado con piezas de más de 8.000 años de antigüedad.

39. Declaraciones en la entrevista personal a Al-Azm por Howard, Elliott y Prohov (2016: 37).

40. Véase "ISIS' Antiquities Sideline", artículo de Amr Al-Azm, Salam Al-Kuntar y Brian I. Daniels publicado en The New York Times el 02/09/2014. Según declaraciones de un intermediario en al-Sayal, el porcentaje solicitado para la concesión de la licencia en esa ciudad era del $60 \%$ (ver "Al-Rikaz Department Of ISIS Licenses Excavation Works In Exchange For Monetary Percentage", publicado en RFS Media Office el 11/03/2016.

41. Datos extraídos de la declaración de Keller (ver supra "Documenting ISIL's Antiquities Trafficking..."). 
prácticas que DAESH incorporó a su estructura, pero que ya se venían realizando con anterioridad. ${ }^{42}$

Este conjunto de datos apunta a la idea de que el grupo se financia con los impuestos aplicados a la concesión de licencias y la supervisión de las excavaciones que los lugareños realizan, pero no apoyan tanto la idea de que comercia directamente con las piezas extraídas. Un análisis de las cifras publicadas así como toda la información disponible lleva a algunos autores a poner en entredicho la vinculación directa de DAESH con las operaciones de venta, lo cual plantea la hipótesis de que el grupo está consintiendo e institucionalizando prácticas de saqueo, pero no participando en ellas como autores materiales. La búsqueda particular de coleccionistas dispuestos a adquirir estas piezas, el control de las redes de distribución y transporte de los objetos, el traspaso de fronteras, la elaboración de documentación falsa para facilitar la circulación internacional y un largo etcétera de pasos implicados en las redes de tráfico de bienes culturales de las que han dado sobradas noticias los intermediarios entrevistados así como los miembros de tramas desarticuladas anteriormente, parece avenirse mal con la estrategia desplegada por DAESH en el territorio ocupado. Resulta evidente que es más eficaz y productivo obtener un impuesto por una actividad que desempeñan otros y garantizarse un ingreso seguro, en vez de negociar las piezas una por una en el mercado negro, lo cual exige tiempo, recursos, conocimientos y, sobre todo, plantea una gran incertidumbre sobre el beneficio que se espera obtener.

Otros académicos apuntan a que las cifras manejadas por los medios se refieren al valor que las piezas incautadas podrían alcanzar como precio final en el mercado occidental de antigüedades, algo que dista bastante del ingreso real que DAESH puede estar consiguiendo con sus impuestos. Sam Hardy ha puesto en cuestión estas cifras ${ }^{43}$ y otros analistas tratan de ponerlas en contexto al replantearse la veracidad de algunas declaraciones, como la realizada por Michael Danti (vid. supra) al señalar el tráfico ilícito como segunda fuente de financiación del grupo, algo que posteriormente ha llegado a matizar ante la ausencia de datos suficientes para sustentar esta afirmación. ${ }^{44}$ Asimismo, muchos se preguntan dónde están todos los tesoros extraídos del país. ${ }^{45}$ Académicos y expertos como Christos Tsirogiannis, arqueólogo forense de la Universidad de Glasgow, ha indicado que no tiene pruebas o información de que el expolio de antigüedades esté financiando las actividades terro-

42. Véase "How antiquities are funding terrorism" publicado en el Financial Times el 29/06/2015.

43. Véase "German Media May Corroborate $\$ 36 \mathrm{M}$ Islamic State Antiquities Trafficking" de San Hardy, publicado en $H y$ perallergic el 28/11/2014. También Al-Azm (Howard, Elliott y Prohov 2016: 37).

44. El investigador Jason Felch ha indagado en conversación personal esta cuestión con Michael Danti. Sus conclusiones pueden leerse en "Danti's Inference: The Known Unknowns Of ISIS and Antiquities Looting", publicado en su blog Chasing Aphrodite el 18/11/2014.

45. Véase "The 'Islamic State' and the illegal Sale of Antiquities", publicado en Abu Susu's Blog el 04/12/2014. ristas. En el mismo sentido se manifiesta Michael Will, director de la unidad de crimen organizado de Interpol, quien no niega la vinculación directa entre el expolio y el conflicto armado, pero afirma carecer de pruebas para vincular la financiación de DAESH con la venta de antigüedades. ${ }^{46}$

\section{¿Posibles conclusiones?}

El informe elaborado en 2016 por la Unidad de Crímenes de Guerra de la policía neerlandesa "Cultural Property War Crimes and Islamic State" 47 se hace eco de la multitud de noticias que circulan por la red sobre esta cuestión, muchas de ellas repetidas e interreferenciadas entre sí. El documento trata de arrojar algo de luz al respecto y buscar la máxima objetividad posible en un terreno tan resbaladizo como este. Por ese motivo, contrasta varias fuentes antes de concluir que, en efecto, se puede afirmar que DAESH está involucrado en el tráfico ilícito de bienes culturales, si bien no es posible determinar el grado de extensión de dicha práctica, ni hasta qué punto constituye una fuente de financiación regular y cuantiosa. Otro tanto concluye el informe elaborado por Brennan y Fitz Gibbon en el marco de trabajo del Committee for Cultural Policy, donde analizan con detalle la información difundida por los medios y denuncian una cierta negligencia en el manejo de las cifras, con fuentes poco contrastadas y partiendo de una recíproca referencia sin demasiado fundamento. En ocasiones se emplean estimaciones generales referidas al volumen total de tráfico ilícito mundial sacadas de contexto e imputadas en exclusividad a la actividad de DAESH. ${ }^{48}$

Estos informes coinciden con la opinión de otros expertos ya citados en señalar que el grupo está heredando conductas ya establecidas con anterioridad al autoproclamado califato. Sin negar la vinculación evidente entre el conflicto y el auge del expolio, muchos autores se preguntan cómo se está desarrollando esta actividad y por qué no afloran más casos en las plazas europeas. ${ }^{49}$ En ese sentido, es muy probable que el impacto del contrabando sea más interno en el propio territorio del país o países ocupados, que más allá de sus límites, donde los mercados estarán sensibilizados frente a este tipo de piezas, cuyo origen es claramente ilegal. Al-Azm explica que las grandes piezas rara vez se verán en anticuarios reconocidos, pues su venta se apalabra particularmente con coleccionistas privados sin escrúpulos. Al mismo tiempo, este autor señala que la mayor parte de los sucesivos traspasos de mano en mano tienen lugar dentro de Siria, sirviendo las porosas fronteras de los países

46. Opiniones tomadas del reportaje "Antiquities: The spoils of war" de Georgina Adams, publicado en el Financial Times el $11 / 03 / 2016$.

47. Informe "Cultural Property War Crimes and Islamic State”, septiembre 2016.

48. Es interesante comprobar la recopilación de titulares realizada en este informe y el recorrido cronológico en las cifras de negocio difundidas por los medios.

49. Así Sam Hardy en "Tax and spend: laissez-faire Islamic State capitalism for the illicit antiquities trade?", publicado en su blog Conflict Antiquities el 05/12/2014. 
limítrofes, especialmente Turquía y Líbano, para la introducción de algunos objetos (Howard, Elliott y Prohov 2016: 10). Por su parte, el periodista Mike Giglio, que ha llevado a cabo varias investigaciones sobre el terreno en la frontera turca, apunta que ha visto salir pocas piezas del país y que es más fácil el traslado de objetos pequeños como monedas. ${ }^{50}$ Asimismo, los profesionales constatan que, tras el estallido de la guerra de Irak, las piezas expoliadas en la zona aparecieron enseguida en el mercado; pero en la actualidad, el gremio de anticuarios está muy sensibilizado con esta cuestión y no se prestan a comerciar con piezas cuyo origen parece sospechoso, entre otros motivos porque se lamentan de estar siendo demonizados injustamente y porque el comercio legal de piezas garantiza precios mucho más elevados que los que se pueden conseguir de forma ilícita. ${ }^{51}$

El hecho de que los casos que afloran en las plazas occidentales sean escasos en comparación con lo que cabría esperar parece respaldar la idea de que la venta de estas piezas se acuerda previamente con compradores particulares y que las características de los objetos se amoldan a unas condiciones apropiadas para su traspaso discreto haciéndolas fáciles de transportar y ocultar, tales como monedas, joyas y objetos pequeños. ${ }^{52}$ De hecho, la reacción de la comunidad internacional se ha disparado en el momento en el que DAESH comenzó a atacar los enclaves arqueológicos declarados patrimonio de la humanidad, lo que no ocultaba un claro afán propagandístico para captar la atención a nivel global. Asimismo, conviene tener presente que este grupo terrorista trabaja con estructuras bien organizadas y que aspira a lograr una sucesión en el poder, por lo que, tan pronto como declaró el califato, procedió a establecer sus estructuras administrativas y políticas, que en gran medida absorbieron al personal y al funcionariado que trabajaba en la administración anterior, aunque fuese bajo amenaza.

The New York Times ha llevado a cabo una profunda investigación sobre la estructura y el funcionamiento de DAESH gracias a los documentos abandonados por el grupo a medida que se recuperaba el control de las principales ciudades. Este proyecto, realizado en cooperación con la Universidad George Washington, ha integrado a otros muchos investigadores que han

50. Ver supra "Antiquities: The spoils of war".

51. Así, por ejemplo, James Ede, expresidente de la International Association of Dealers in Ancient Art (Ver supra "Antiquities: The spoils of war"). El estado actual de la deontología profesional del gremio contrasta con la advertida en períodos anteriores con piezas procedentes de zonas en conflicto, como el reportaje "Blood antiques" registró en relación con antigüedades afganas entre 2005 y 2009.

52. Esta es la opinión de Patty Gerstenblith, profesora de derecho en DePaul University y experta en el mercado de antigüedades. Vid. "Antiquities Dealer Sues Wall Street Journal Over ISIS Article", publicado en The New York Times el 17/07/2017. Entre el tipo de piezas confiscadas a su entrada en las plazas europeas, podemos citar el ejemplo de varias monedas y objetos de cristal interceptados a su llegada a Londres, de lo que da noticia The Washington Post en su publicación "Islamic State is selling looted Syrian art in London to fund its fight" del $25 / 02 / 2015$ trabajado para tratar de descifrar los secretos del autoproclamado califato. Gran parte de sus hallazgos se han puesto a disposición del público desde abril de $2018 .^{53} \mathrm{El}$ análisis de estos archivos permite concluir que una de las claves del éxito de DAESH reside en haberse establecido como un grupo autofinanciado y en haber acompañado su expansión militar con una estudiada estrategia burocrática para establecer un gobierno real. Por esta razón, mantuvieron en gran medida las estructuras administrativas preexistentes, con su cuerpo de funcionarios, y reestructuraron los ministerios para adaptarlos a su ideología. Esta fuerte burocratización discurría de forma paralela a sus ideas de fanatismo religioso y al establecimiento de un rígido sistema impositivo que garantizaba la obtención de recursos económicos y la redistribución de los bienes entre quienes consideraban genuinos creyentes. El resultado fue una férrea administración que supervisaba todo tipo de actividades, desde las más cotidianas, y un sistema tributario implacable que gravaba las más variadas acciones, desde la venta de melones a la leche del ganado. Asimismo, en base a sus manifiestos de fe, incautaban los bienes y las tierras que pertenecían a miembros de otras facciones religiosas y los reasignaban a sus creyentes. Con la confiscación de bienes, debidamente documentada bajo la forma de una "donación" o "contribución" voluntaria, el califato estaba abastecido de todo lo necesario. Este esquema describe una estructura institucional de utilidad estratégica pensada para mantener el control del territorio, garantizar su sustento económico y construir la antigua visión de un califato que se expandía por todo Oriente Medio.

El conjunto de documentación recuperada en este proyecto, junto con la requisada en sucesivas operaciones militares que ya hemos mencionado, demuestra que DAESH centraba sus esfuerzos en mantener una estructura operativa y una administración eficaz, especialmente en lo que respecta a la recaudación de impuestos. Es más, parece deducirse que es mucho más productivo para ellos mantener una maquinaria eficaz en el cobro de tributos que tratar de realizar las operaciones ellos mismos, lo cual habría requerido una gran inversión de recursos humanos y logísticos.

Una de las primeras medidas adoptadas por el califato fue la reestructuración ministerial y la creación de un departamento específico sobre recursos naturales, centrado en la gestión de las riquezas naturales halladas en el suelo del territorio de las que obtener beneficios, incluyendo, claro está, el petróleo y el gas, pero también las antigüedades, ${ }^{54}$ a través de unidades específicas dentro del ministerio. No obstante, la existencia de documentación tratando de

53. “The ISIS' files” publicado en The New York Times el 04/04/2018. Puede accederse a una selección de los documentos hallados y su síntesis en inglés en: <https://www.nytimes.com/ interactive/2018/04/04/world/middleeast/isis-documents-photos. html >. Para conocer más sobre el proyecto académico realizado en cooperación con la Universidad George Washington, ver: $<$ https://lai.gwu.edu/archiving-terror-isis-files $>$.

54. "The Archivist: Unseen Documents from the Islamic State's Diwan al-Rikaz", por Aymenn Jawad Al-Tamimi, publicado el 12 de octubre de 2015. 
establecer un orden en las conductas y la necesidad de contar con licencias para la excavación se aviene mal con la idea de que DAESH ha procedido a un expolio indiscriminado y no calculado. Los documentos obtenidos por los investigadores y por las fuerzas militares dibujan un panorama estructurado en el que la extracción de objetos arqueológicos requiere de permiso previo, así como la exportación de esas piezas fuera del territorio del califato. Aymenn Jawad Al-Tamimi, investigador del Jihad Intel, dentro del Middle East Forum, y colaborador del proyecto "Isis' files", ha aportado valiosísima información sobre el funcionamiento administrativo de este grupo y destaca un documento emitido en el momento de la ocupación de Palmira, en el que el Ministerio de Recursos Naturales prohíbe la extracción y comercialización de toda clase de objetos de valor histórico hallados en el enclave arqueológico.55 Similares documentos se referencian en el informe de la policía neerlandesa ya mencionado en relación con los municipios de Homs y Alepo. De acuerdo a al-Azm este es el modo en que DAESH ha "institucionalizado" las redes de contrabando que ya existían con anterioridad. ${ }^{56}$

Recopilando algunos comentarios de profesionales en el mercado de antigüedades y de académicos y especialistas en el estudio del patrimonio cultural árabe y particularmente el sirio, lo cierto es que no es posible determinar, ni siquiera de forma aproximada, el volumen de ingresos que este comercio ilegal puede reportar. ${ }^{57} \mathrm{En}$ el informe de la policía neerlandesa menciona varias de estas publicaciones para mostrar la disparidad en la valoración de los ingresos estimados (de hasta 200 millones de dólares), y se remite finalmente al proyecto de investigación MANTIS, sobre tráfico ilícito de bienes sirios e iraquíes, llevado a cabo por la Universidad de Chicago, en el que se deduce que DAESH no obtiene apenas ingresos por esta vía sino en sus propios territorios, y que las afirmaciones de las que se hacen eco los medios de comunicación no están apoyadas en pruebas. ${ }^{58}$

Por otro lado, muchas piezas han resultado ser falsas, y se hacen pasar por auténticas. Además de eso, se pone en duda el volumen de piezas que se pueden considerar hoy introducidas en el mercado. El conjunto global del sector es consciente de lo sensible de la cuestión y no se arriesgaría a comerciar con piezas procedentes de una región de la que no se puede tener constancia fehaciente de su origen lícito. Los anticuarios de prestigio no deberían caer en ese error y echar por tierra su reputación profesional.

55. Vid. "The Archivist: 26 Unseen Islamic State Administrative Documents: Overview, Translation \& Analysis" por Aymenn Jawad Al-Tamimi, publicado el 24 de agosto de 2015 .

56. "Looted in Syria - and sold in London: the British antiques shops dealing in artefacts smuggled by Isis", publicado en The Guardian el 31/07/2015.

57. Solo como referencia se pueden mencionar los ingresos detallados en la documentación requisada por el ejército norteamericano tras abatir a Abu Sayyaf, donde se registran 24 millones de libras por venta de antigüedades. Vid. supra "Islamic State: Looting for Terror" (BBC Radio 4).

58. "Inside ISIS' looted antiquities trade", publicado en The Conversation el 31/06/2016.
El testimonio de los intermediarios entrevistados hace referencia a países de destino final de las piezas, como Francia, Alemania, Reino Unido, Suiza, EE. UU.... pero los representantes del sector del mercado de antigüedades de estos países declaran que no hay constancia de ese supuesto surgimiento de un mercado negro tan nutrido como debería, a la luz de las excavaciones masivas que se pueden registrar por satélite. Así se ha expresado Christopher Marinello, director de Art Recovery Group. En su opinión, la idea de que existe un mercado occidental dispuesto a comprar las piezas es lo que anima a los marchantes de Oriente a alimentar la red de contrabando, pero no hay apenas evidencias de que las plazas europeas se estén nutriendo del contrabando de objetos sirios..$^{59}$ No obstante, en otra entrevista realizada por Simon Cox para la BBC Radio 4, Marinello relata el caso de un marchante inglés involucrado en una demanda sobre una pintura del siglo xIX que quiso negociar la resolución del caso prestando su colaboración para ubicar una serie de piezas que claramente habían sido expoliadas desde Siria, y afirmó que existe, de hecho, un mercado para estas piezas en Europa, porque aquí es donde están los principales coleccionistas y plazas de negocio.

Para otros expertos, el comercio de estas piezas solo es posible cuando no existen registros previos $\mathrm{y}$, por tanto, la ausencia de informes e inventarios permite reconstruir un origen falso para las antigüedades, en opinión de Mark Altaweel, arqueólogo de la University College London, ${ }^{60}$ idea que también se expresa en el reportaje elaborado por el Wall Street Journal y emitido en mayo de 2017, que explica que muchas de estas piezas se almacenan en puertos francos, como en Ginebra o Dubái, y se pasan de uno a otro hasta que el origen de los objetos está suficientemente desdibujado como para crear uno nuevo y falso. ${ }^{61}$ En este sentido, Cristina Menegazzi, oficial de la UNESCO en Líbano, declara que no se pueden aportar cifras de negocio exactas sobre el tráfico de bienes culturales, a pesar de que hay pruebas de que existe tal tráfico y de que se han confiscado piezas en las fronteras que, sin embargo, no salen a la luz en el mercado. En su opinión, es probable que esos objetos afloren dentro de cinco, diez, veinte años o incluso más; por eso lo importante es centrarse ahora en bloquear esas posibles ventas. ${ }^{62}$

59. Vid. supra "Inside the Underground Trade to Sell Off Syria's History" (BuzzFeed News).

60. Vid. supra "Inside the Underground Trade to Sell Off Syria's History" (BuzzFeed News).

61. Vid. supra "ISIS Is Selling Syria's Antiquities to the West" (WSJ). Esta misma opinión es compartida por Al-Azm y Richard Ellis, investigador sobre delitos culturales y antiguo colaborador de Scotland Yard en la unidad de Art \& Antiques Squad, quien señala que la forma de introducir las piezas expoliadas en el mercado pasa por reservarlas en puertos francos y cajas fuertes de Zúrich o Ginebra, donde permanecen unos 15 o 20 años antes de insertarlos en el mercado legal de antigüedades (ver reportaje de John Wilson para BBC Sounds: <https://www. bbc.co.uk/sounds/play/b04n695f >). $4)$. 


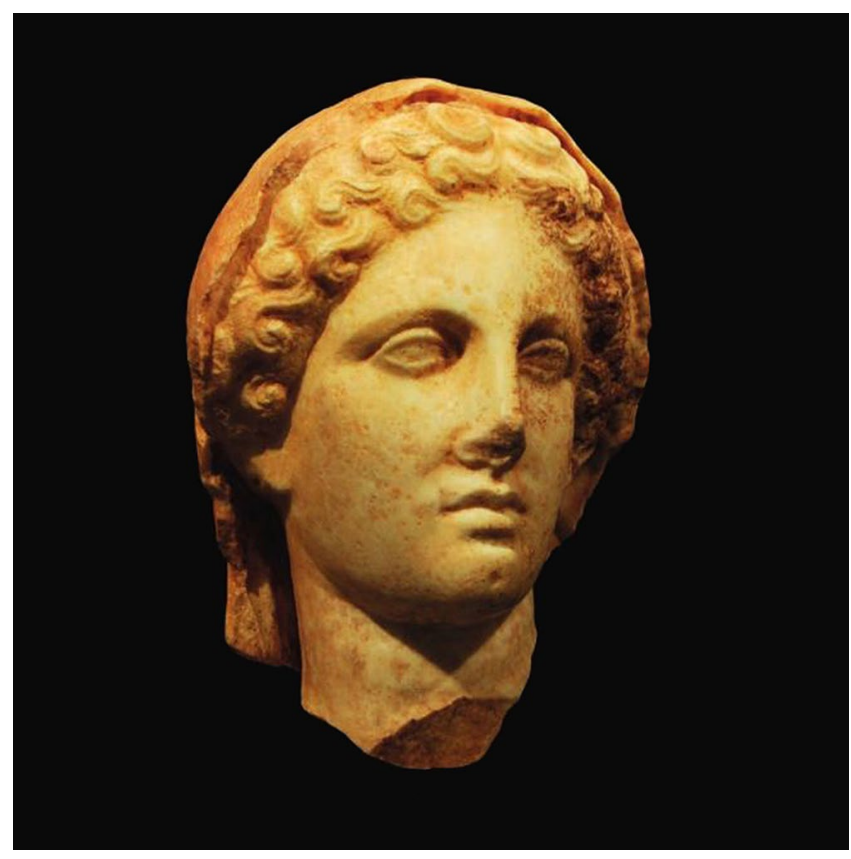

Figura 1. Catálogo Brafa 2016, p. 59.

"Cabeza de diosa con velo".

Mármol. Grecia, siglo Iv a. C. A. $36 \mathrm{~cm}$.

Procedencia: colección privada S. G., Bélgica, adquirido en la década de 1950.

\section{La red de comercio de antigüedades destapado en España}

A finales de marzo de 2018 la Policía Nacional española detuvo en Barcelona a dos anticuarios por su presunta participación en una red de comercialización de antigüedades procedentes de Libia que servía para financiar a DAESH. Es la primera operación policial en la que se trata de demostrar la financiación directa del grupo terrorista mediante el expolio de piezas arqueológicas. A pesar de los numerosos intermediarios y de los esfuerzos por ocultar el origen de los objetos, tanto el seguimiento del dinero como el de los bienes permite vincular sin lugar a dudas esta operación con ISIS. Según fuentes policiales, el anticuario barcelonés es uno de los diez marchantes que están siendo investigados en Europa por su participación en redes de tráfico ilícito de antigüedades. ${ }^{63}$

En esta investigación la alerta de Morgan Belzic jugó un papel determinante. Se trata de un historiador francés que estaba desarrollando sus estudios de doctorado sobre el patrimonio de Cirene ("Les sculptures funéraires de Cyrénaïque"), dentro de un equipo de trabajo de la École Pratique des Hautes Études ${ }^{64}$ Su labor, en cooperación con misión francesa arqueológica y las autoridades libias de protección del patrimonio, consistía en documentar las antigüedades y piezas funerarias de la región norte del país en Shahhat (Cirene), Susa (Apolonia), Tulmayta

63. Revelado en conversación privada con la Brigada de Patrimonio Histórico de la Policía Nacional de España.

64. Belzic (2017).

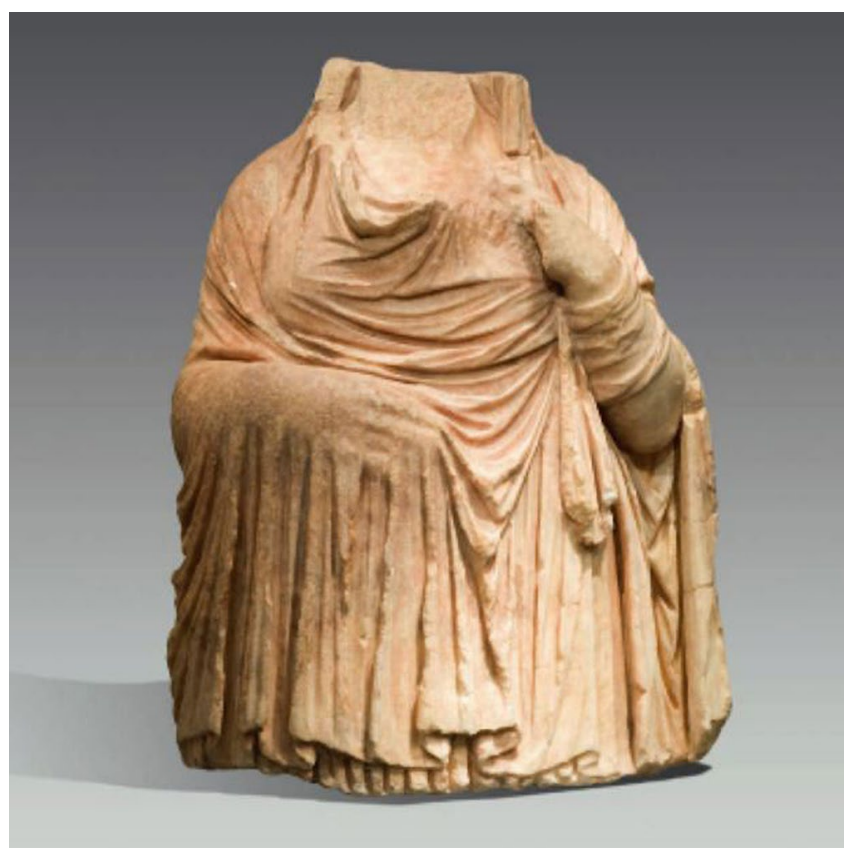

Figura 2. Catálogo Brafa 2015, p. 60. "Deméter o Perséfone".

Mármol. Cirene, circa siglo IV a. C. A $67.3 \mathrm{~cm}$. Procedencia: colección privada europea, 1960.

(Ptolemaida), Tocra (Taucheira) y Bengasi (Hespérides/ Berenice). En el curso de su trabajo pudo comprobar que las tumbas del territorio estudiado habían sufrido numerosos saqueos en los últimos veinte años, y muy especialmente en la última década. Uno de los hechos que desató las alarmas para Belzic fue la constatación de que varias piezas ofertadas a la venta en el mercado europeo procedían inequívocamente de esta región, y particularmente de la zona cirenaica. ${ }^{65}$ Parecía haber una correlación entre la creciente destrucción de monumentos funerarios en la zona y la aparición de más piezas en el mercado.

Belzic identificó varios objetos ofrecidos en venta en una feria de antigüedades de Bélgica por parte del anticuario que no ofrecían duda alguna sobre su procedencia. Incluso aunque los bienes no estuviesen catalogados con anterioridad, y por tanto no se pudiesen contrastar inventarios (lo cual solo podría indicar que procedían de una excavación ilegal), las piezas funerarias de esta zona tienen unas características inconfundibles y un estilo escultórico único que posibilita su identificación y su vinculación inequívoca con esta área.

Cirene es una ciudad griega ubicada en la costa mediterránea de Libia, fundada en el siglo vII a. C., que perduró hasta el siglo Iv d. C., cuando un terremoto la destruyó parcialmente y fue abandonada. Luego, con el paso del tiempo, quedó cubierta de arena y olvidada hasta su descubrimiento en el siglo xvIII. Fue 
un emplazamiento enormemente próspero. Se estima que contaba con unos 100.000 habitantes y disponía de numerosos edificios y monumentos, entre ellos, un templo dedicado a Zeus, que casi igualaba en tamaño al del Panteón, y otro dedicado a Apolo. A día de hoy se calcula que solo se ha desenterrado el $20 \%$ del total de la superficie de este antiguo asentamiento. Cirene fue declarada Patrimonio de la Humanidad en 1982 e incluida en la lista de patrimonio cultural en peligro en $2016 .^{66}$

Belzic consiguió rastrear varios objetos ofrecidos en venta en distintos lugares de Europa. Un total de 105 esculturas funerarias, lo que representa entre un $15 \%$ y un $20 \%$ de todas las conocidas hasta el momento, lo que da a entender que es muy probable que haya muchas más disponibles en el mercado negro de las que no se tiene noticia. El historiador identifica varias piezas, a la venta también en casas de subastas y otros anticuarios, pero en el caso concreto del anticuario español señala y describe ocho objetos, no documentados previamente, cuya procedencia es inequívoca. Al parecer, algunas de estas esculturas fueron ya vendidas desde que se comenzaron a ofertar en 2014. En su opinión, el comerciante conocía a ciencia cierta la naturaleza de los bienes y maquillaba su origen con referencias vagas a colecciones particulares anteriores

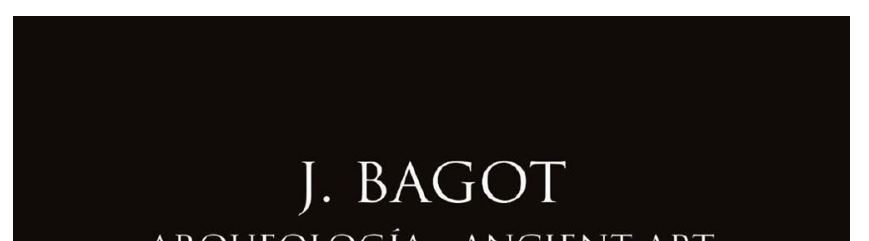

ARQUEOLOGİA - ANCIENT ART

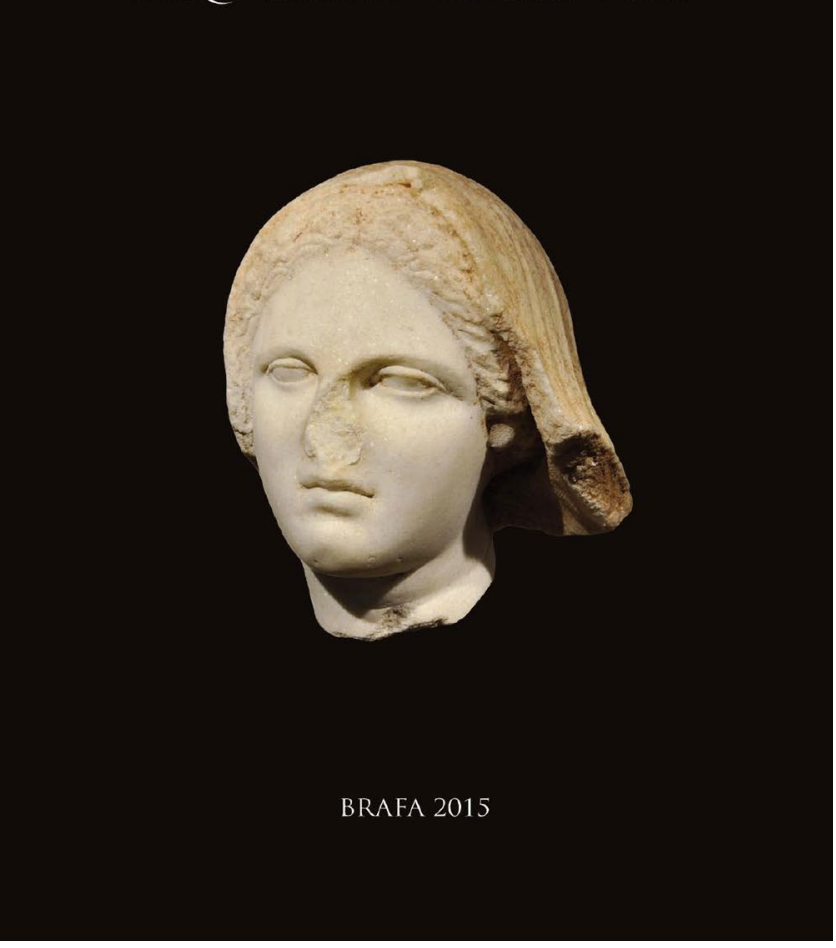

Figura 3. Portada del catálogo del anticuario detenido (J. B.) elaborada para participar en la feria BRAFA en 2015 La imagen de la portada es una de las piezas procedentes de Libia supuestamente expoliadas.

66. <https://whc.unesco.org/en/list/190/> a 1970. El descaro era tal, que llegaba a usar estos tesoros para ilustrar sus catálogos en la feria Brafa, uno de los eventos más reputados en la venta de antigüedades, que tiene lugar en Bruselas.

La investigación tomó un nuevo impulso cuando la policía española recibió una petición de colaboración por parte de la policía italiana. "Nos solicitaron información sobre un sarcófago que podía haberse vendido por contrabando en Bélgica, pasando por España y por las manos del detenido principal", declara Fernando Porcel, jefe de la Brigada de Patrimonio de la Policía Nacional española. ${ }^{67}$ Aunque las pesquisas policiales comenzaron hacía tres años, un conjunto de circunstancias recientes precipitaron los acontecimientos que llevaron a la detención de estos dos anticuarios el 27 de marzo de 2018. Se enfrentan a los cargos de delitos de financiación del terrorismo yihadista, receptación, falsedad documental y contrabando. Antes de su detención, la UDEV Central de la Comisaría General de Policía Judicial y de la UCIE de la Comisaría General de Información llevaron a cabo cinco registros minuciosos en los establecimientos de Argentona y Barcelona propiedad de los anticuarios, donde se incautaron numerosos objetos arqueológicos, además de material informático y abundante documentación. ${ }^{68}$ En el comunicado informativo de la Brigada de Patrimonio Histórico difundido a través del Ministerio del Interior de España no se acompaña una lista de los bienes confiscados. Se ha filtrado a la prensa que, entre las piezas halladas durante los registros, hay siete sarcófagos, $\mathrm{y}$ varios mosaicos $\mathrm{y}$ piezas de origen egipcio y libio. Se estima que su precio de mercado oscilaba entre los 30.000 y más de 250.000 euros. ${ }^{69}$

Tras haber pagado su fianza y ser puesto en libertad, el principal encausado aseveró en una entrevista ${ }^{70}$ que desconocía que las piezas tuviesen un origen ilícito, y que todas sus adquisiciones se realizaron de buena fe y a través de comerciantes de reconocido prestigio. Asimismo, declaró que nunca compró a marchantes libios, sirios o iraquíes, y que la procedencia de las piezas que compra es legítima y que puede aportar documentación al respecto. Aunque en esta entrevista dijo no conocer el listado final de las piezas requisadas, comenta que en los medios de comunicación ha visto la imagen de una cabeza, de la que puede enseñar la factura, que fue comprada a Bonhams en febrero de este mismo año. Por otro lado, el anticuario señala que ha comunicado a la

67. "Jaume Bagot, el anticuario del expolio libio descubierto por un estudiante belga”, publicado en Cadena Ser el 28/03/2018.

68. "La Policía desmantela una red que comerciaba con obras de arte expoliadas en Libia que servían para financiar el terrorismo yihadista", publicado en la web oficial del Ministerio del Interior de España, 28/03/2018. Tras su puesta a disposición judicial, el magistrado de la Audiencia Nacional Diego de Egea ha acordado su puesta en libertad con cargos y bajo fianza de 12.000 euros, con obligación de comparecencias periódicas ante la justicia y la prohibición de salir de España (ver "Jaque a las antigüedades de sangre”, publicado en el $A B C, 01 / 04 / 2018$ ).

69. "El «niño prodigio» del arte antiguo que financió a Daesh", publicado en $A B C, 01 / 04 / 2018$.

70. "Nunca en la vida he comprado piezas de Irak, Libia o Siria", publicado en Crónica Global, 30/03/2018. 
unidad de Patrimonio Histórico del Ministerio de Cultura todas las importaciones realizadas, acompañadas de las respectivas facturas de compra y fichas descriptivas. Esta declaración, amparada en el art. 32 de la Ley de Patrimonio Histórico Español, presenta una serie de ventajas fiscales y comerciales, que en la esfera del comercio de antigüedades es de crucial importancia. En opinión del marchante, el caso se ha iniciado por una mala interpretación de estas declaraciones, porque él está en disposición de justificar la procedencia y la adquisición de las obras requisadas, aunque, admite, "Son objetos que compramos en establecimientos públicos y a comerciantes conocidos que se aseguran de dónde provienen los objetos. Yo no puedo asegurar al cien por cien que uno o dos de los 4.000 objetos que tengo pueda proceder de un robo, pero en ningún caso es intencionado. Yo no tengo acceso a los documentos, no sé si son robados o no. Debo suponer que no". En efecto, el volumen de solicitudes de importación fue uno de los cabos por los que la investigación siguió desarrollándose, como explicaremos más adelante.

A pesar de estas explicaciones, el conjunto de indicios parece apuntar a la existencia de una trama de tráfico ilícito de bienes culturales procedentes de Libia para introducirlos en el mercado europeo con amplio margen de beneficio. Recordemos que, según la identificación de piezas llevada a cabo por Belzic, esta red de comercialización de piezas libias no se ciñe exclusivamente al anticuario barcelonés, sino que también afectaba a otras plazas de venta, incluyendo casas de subastas, museos y ferias de antigüedades. Lo alarmante del presente supuesto es que aparentemente se ha podido vincular de forma inequívoca el contrabando de estos objetos con la financiación del DAESH. A este respecto, Porcel indica que no ha sido fácil seguir el dinero ni seguir el rastro de las piezas para reconstruir esos nexos. A lo largo de este tiempo de trabajo han logrado identificar la fuente de los bienes así como a cuatro intermediarios habituales que proveían también a otros marchantes europeos, ${ }^{71}$ todo ello gracias también a la intervención de las comunicaciones, donde se pudo detectar los acuerdos para manipular los valores de los objetos, la descripción falsa de piezas y los precios de venta acompañados de fotografías, en una investigación en la que se analizaron más de 34.000 correos electrónicos. ${ }^{72}$

Este supuesto responde a la perfección al patrón de conducta descrito en otros casos sacados a la luz recientemente, en los que se trata de ocultar y dificultar el rastreo de la ruta de distribución a través de la colaboración de numerosos intermediarios y trasladando las piezas a terceros países para depurar el proceso de importación. Es una red que blanqueaba los bienes, ya que se trataba de regularizar un flujo constante de abastecimiento de piezas que no se podía lograr con las ventas puntuales y preacor-

71. "De los anticuarios de lujo a las arcas del terrorismo islamista”, publicado en El País, 04/05/2018.

72. Declaraciones de Fernando Porcel en el "Encuentro internacional para el desarrollo" de 27 y 28 de noviembre 2018, disponible en <https://www.youtube.com/watch?v=bRqGbI9ddhM $>$. dadas. El objetivo era dar el salto al comercio legal y ofrecer los objetos en las plazas más prestigiosas para obtener los mejores precios. Por otro lado, los comerciantes serios y respetados y los coleccionistas no quieren ver comprometida su reputación, por lo que es necesario limpiar el origen de los bienes para despejar sospechas al respecto.

Algunas de las piezas incautadas procedían de las regiones de Albaida, Apolonia y Cirene, yacimientos situados al norte de Libia. Para su identificación, la policía contó en todo momento con la colaboración de las autoridades libias, encauzada a través de su embajada. Según declaraba recientemente Walid Abuabdalla, encargado de negocios de la embajada libia en España, "Calculamos que hay entre 19 y 23 piezas que están en Europa y más de la mitad, en España”. ${ }^{73}$ Estas zonas estuvieron bajo dominación de DAESH desde 2011 hasta 2016. Si bien Libia no ha sido un país cuyas riquezas arqueológicas hubieran tenido una gran demanda en el mercado de antigüedades, lo que disuadía a los contrabandistas de atacarlas por falta de potenciales compradores, el impacto de un conflicto armado provocó un cambio en esta situación. Durante el período de ocupación, la inestabilidad social y política acarreó graves consecuencias para la conservación de algunos de sus principales yacimientos, situados en su mayoría en el área próxima a la costa, con importantes deterioros no solo imputables a los desastres bélicos. De hecho, se reportan actos de ocupación del terreno y aprovechamiento de las tierras por parte de los habitantes locales, y la total desatención de los sitios arqueológicos. ${ }^{74}$ En este contexto, se producen varios robos y saqueos, difíciles de cuantificar y perseguir por parte de las autoridades nacionales libias, no solo por la falta de mayores medios, habida cuenta del contexto de enfrentamiento armado del momento, sino también por la imposibilidad de rastrear piezas de las que no hay registros, ni inventarios ni fotografías por haber sido excavadas de forma ilegal.

Algunas de las esculturas de cabezas y torsos griegos y romanos incautadas en esta operación procedían de Cirene. Durante el registro pudo comprobarse que algunos de estos objetos conservaban aún tierra y arena del lugar de la extracción. ${ }^{75}$ Las excavaciones y los traslados eran apresurados y realizados sin el menor cuidado. Las obras presentaban importantes deterioros, golpes e imperfecciones, debido en gran medida a su retirada acelerada y a la fuerza, por lo que debían someterse a un proceso de restauración antes de su puesta en circulación. ${ }^{76}$ A esta labor se dedicaba el depósito que los detenidos tenían en Argentona.

73. Vid. supra "De los anticuarios de lujo [...]" (El País).

74. Vicent Michel (2014: 72-74).

75. Vid. supra "El «niño prodigio» del arte antiguo que financió a Daesh" $(A B C)$.

76. Vid. supra "La Policía desmantela una red que comerciaba con obras de arte [...]". 


\section{Modus operandi}

Los detenidos contaban con varios intermediarios que les ayudaban en las tareas de localización, extracción y traslado de las piezas. Un mercader libanés y otro egipcio actuaban como marchantes intermedios y servían de enlace entre los saqueadores, autores materiales de las excavaciones, y los destinatarios en España, que compraban las piezas a estos comerciantes. Esta cadena de comando funcionaba con fluidez, de modo que las piezas llegaban a la galería para su comercialización en muy poco tiempo. Se tiene noticia de unos objetos desenterrados en mayo de 2017 que cuatro meses más tarde ya estaban a la venta, así como otros robos en enero ofertados al público apenas dos meses después. ${ }^{77}$

\section{SAQUEADOR > MARCHANTE INTERMEDIARIO > ANTICUARIO}

\section{Rutas de distribución: análisis de la normativa implicada}

La otra parte del proceso, y quizás la más complicada, tenía que ver con el traslado de las piezas. Los objetos se importaban a España desde terceros países, con el fin de ocultar su verdadera procedencia. Entraban en nuestro país a través de dos rutas principales:

- Ruta por Oriente Medio: los bienes se trasladaban a Egipto o Jordania, desde ahí se enviaban por mar a Emiratos Árabes. A continuación se introducían en Europa, con escala en Alemania, antes de su llegada a Barcelona.

- Ruta por Asia: los bienes se trasladaban a Tailandia y desde allí se importaban a Europa.

Las rutas de contrabando que discurren por Oriente Medio eran ya habituales. El saqueo de objetos arqueológicos de los últimos años no hizo sino aprovechar las redes de distribución y comercio clandestino que se empleaban ya con anterioridad tanto para armas, como para bienes culturales de otro origen, piezas egipcias o iraquíes, que solían blanquearse en Líbano o Turquía, como ya hemos visto. No obstante, la sensibilización y alerta internacional a este respecto, particularmente desde los convulsos episodios ocurridos durante la Primavera Árabe, y los numerosos conflictos que afloraron en varios países de la región, comenzaron a desaconsejar el uso de estas mismas rutas. La normativa de estos países prohíbe la salida de los tesoros históricos de sus territorios, como luego veremos, de modo que urdir todo un mecanismo de vías de transporte, documentación asociada y certificados de origen falsos se hacía cada vez más complicado. Por este motivo, el traslado de las piezas a Asia comenzó a ser frecuente, ya que los acuerdos comerciales con Europa y la mayor flexibilidad en el traslado de mercancías hacía más fácil el blanqueo.

Uno de los aspectos que levantó sospechas en España fue el aumento del número de declaraciones de importación de obras griegas y romanas proce-

77 Vid. supra "Jaque a las antigüedades de sangre" $(A B C)$. dentes de una misma región, todas ellas realizadas entre 2013 y $2015 .^{78} \mathrm{El}$ análisis de estos documentos planteó una serie de incógnitas que parecían apuntar en una única dirección: el contrabando. Los bienes se introducían muchas veces bajo categorías falsas, descritos como objetos decorativos con un valor irrisorio para abaratar los aranceles aduaneros y evitar inspecciones. En otras ocasiones, se apreciaban contradicciones entre el origen declarado de los bienes y el lugar de expedición de las facturas. Se aportaban facturas de Turquía o Egipto para bienes traídos de Asia. También resultaba sorprendente la cantidad de objetos importados desde países, incluida Libia, donde la salida de tesoros arqueológicos está prohibida. Todo esto llevó a pensar que las facturas y los expedientes eran falsos.

La procedencia declarada de estas piezas llamó la atención de la Brigada de Patrimonio de la Policía Nacional española porque la legislación de los países indicados no permite la exportación de bienes culturales. Haremos un repaso a esta normativa para entender el porqué de esta forma de actuación y la razón de que los procesos de importación levantasen sospechas.

La legislación de Libia, Egipto y Turquía es muy similar en cuanto al nivel de protección aplicable a sus riquezas culturales y a las prohibiciones de exportación contempladas. A continuación, extractamos las principales disposiciones al respecto.

\section{A. Libia}

Ley N. ${ }^{\circ} 3$ de 1424 P. B. (1994) para la Protección de Antigüedades, Museos, Ciudades Antiguas y Edificios Históricos (29 de agosto, 1994). ${ }^{79}$

\section{Artículo 25}

Nadie puede llevar a cabo excavaciones arqueológicas sin un permiso de la autoridad competente, incluso si él es el propietario del lugar donde se lleva a cabo la excavación.

Las excavaciones arqueológicas no están permitidas, excepto para los arqueólogos y las misiones arqueológicas, que están formadas por asociaciones, institutos e instituciones científicas, de conformidad con las condiciones especificadas por el reglamento ejecutivo.

\section{Artículo 26}

Todos los efectos descubiertos por el licenciatario de las excavaciones serán propiedad del Estado. El licenciatario tendrá, después de la aprobación por escrito de la autoridad competente, los siguientes derechos:

A) Tomar moldes de yeso o copias similares de los artefactos descubiertos, siempre que dichos efectos no los dañen.

B) Tomar algunas fotos, dibujos y mapas necesarios para identificar los efectos hallados.

78 Declaraciones de Fernando Porcel (ver supra "Encuentro internacional para el desarrollo").

79. <http://www.unesco.org/culture/natlaws/media/pdf/libye/ libya_cltherlaw_94_arorof $>$. Se ofrece en este artículo una traducción orientativa, ante la dificultad de hallar una traducción oficial de la norma en inglés, francés o español. 
En Libia, la legislación declara propiedad del Estado todos los hallazgos arqueológicos, y establece restricciones a la exportación. Las excavaciones solo son posibles previa obtención de una oportuna licencia.

\section{B. Egipto}

Ley N. ${ }^{\circ} 117$ de 1983, sobre la Protección de Antigüedades $^{80}$

\section{Artículo 6}

Todas las antigüedades se consideran propiedad pública excepto los wakfs. Su posesión o titularidad o transmisión no está permitida excepto en los términos y condiciones estipulados en la presente ley y en los decretos de desarrollo.

\section{Artículo 9 (1.er inciso)}

El poseedor de una antigüedad puede disponer de ella en cualquier forma de disposición después de haber obtenido de la autoridad competente aprobación por escrito, de acuerdo con los procedimientos y reglas contemplados en el decreto promulgado por el ministro de asuntos culturales, siempre que dicha disposición no resulte en transferir la mencionada antigüedad fuera del país.

\section{Artículo 41}

Quien haga contrabando con una antigüedad fuera de la República o participe en dicho acto será castigado con trabajos forzosos temporales o con una multa no inferior a 5.000 libras egipcias y no superior a 50.000 libras egipcias. En este caso, la antigüedad, objeto del crimen, será confiscada en nombre de la autoridad junto con el equipo, instrumentos, maquinaria y vehículos usados en el crimen.

Hay que señalar, además, que Egipto ha suscrito varios acuerdos bilaterales para luchar contra el tráfico ilícito de bienes culturales y facilitar su rápida restitución, con Perú (2005), Cuba (2008), Ecuador (2008), Italia (2008), Suiza (2010), China (2010) y Jordania (2015). Estos acuerdos se basan en los compromisos adquiridos por los estados parte al ratificar la Convención de la UNESCO de 1970 y plasman una voluntad de cooperación internacional para permitir una rápida devolución de piezas obtenidas ilícitamente a su país de origen. Hay que tener en cuenta que en muchas ocasiones, estos convenios tratan de llegar donde las grandes convenciones no pueden, ya que los tratados exigen una alto grado de consenso en el que ha de sacrificarse la amplitud del alcance para hacerlo viable.

\section{Turquía}

Ley de Conservación del Patrimonio Cultural y Natural N..$^{\circ} 2863$ de 23 de julio de $1983^{81}$

\section{Prohibición de sacar al extranjero}

\section{Artículo 32 (1. er $^{\text {inciso) }}$}

Los bienes muebles del patrimonio cultural y natural protegido en el país no pueden sacarse al extranjero. No obstante, a condición de que las autoridades extranjeras proporcionen garantía y seguro contra la posibilidad de cualquier tipo de daño, pérdida, amenaza o violación, y en respeto de los intereses nacionales, el Consejo de Ministros puede autorizar una exposición temporal en el extranjero y la devolución de los bienes, siguiendo la decisión de un comité de científicos compuestos por directores de arqueología e historia del arte de instituciones de educación superior y la propuesta del ministro de Cultura y Turismo.

\section{Traer patrimonio al país}

\section{Artículo 33}

Se pueden introducir libremente en el país bienes culturales.

La legislación turca sigue una pauta proteccionista de su patrimonio cultural que es ampliamente compartida por las normativas recientes a nivel mundial, especialmente las promulgadas tras la entrada en vigor de la Convención de la UNESCO de 1970. Este tratado supuso una declaración de principios de carácter más programático que práctico, pero obligó a muchos estados miembro a aprobar o a actualizar sus respectivas leyes, en el ámbito de la protección de sus tesoros culturales. Es llamativo, no obstante, que el art. 33 de la ley turca establezca que se pueden introducir libremente en el país bienes culturales, algo que también sucede en muchos ordenamientos jurídicos, si bien las normas no suelen ser tan explícitas. Ante este tipo de disposiciones, es evidente que el control de esa entrada de bienes en el país descansa sobre las autoridades aduaneras, porque el artículo no busca favorecer el tráfico ilícito, sino enriquecer el patrimonio cultural nacional con bienes traídos (legalmente) de fuera.

\section{Tailandia}

A diferencia de la normativa de los países que acabamos de exponer, la legislación tailandesa de patrimonio cultural no prohíbe la exportación de bienes arqueológicos, antigüedades y obras de arte. Como ya había apuntado Susan Kane, directora del proyecto "Cyrenaica Archaeological Project", de la Universidad Oberlin de Ohio, ${ }^{82}$ esta circunstancia se está aprovechando por los traficantes para crear nuevas rutas de distribución de objetos expoliados, especialmente los procedentes de Oriente Medio. En efecto, la Ley sobre Monumentos Antiguos, Antigüedades, Objetos de Arte y Museos Nacionales, B.E.2504 (1961), ${ }^{83}$ no prohíbe la exportación de bienes culturales, únicamente exige la obtención de una licencia previa de actividad, sea para objetos ya registrados o no. Además, contiene disposiciones detalladas sobre la obtención de dichos permisos y las tasas administrativas que se han de abonar por quienes se dedican al comercio de estos objetos, así como para quienes gestionan su tránsito a través del país. En el capítulo sobre sanciones, contempla penas para el caso de que los bienes se saquen del país sin haber obtenido la oportuna licencia previa (secciones 38 y 39). Asimismo, establece que si el gobierno dispone ya de suficientes piezas
80. <http://www.unesco.org/culture/natlaws/media/pdf/egypt/ egypt_law117_1983_engtof.pdf >.

81. <http://www.unesco.org/culture/natlaws/media/pdf/turkey/ turkey_lawconservationculturalnaturalproperty_1_entof $>$.
82. "Libia: a rischio anche decine di tesori archeologici, stilata la «red list»", publicado en Corriere della Sera el 04/03/2016.

83. <http://www.unesco.org/culture/natlaws/media/pdf/thailande/thai_actcltmon_61_entof>. 
representativas de una determinada tradición, estilo o época, puede acordar su disposición para otros fines, incluido el comercio.

En el régimen tailandés, los bienes culturales pueden ser objeto de propiedad privada así como de propiedad pública, pero no hay una disposición que declare a estos objetos como constituyentes de un patrimonio cultural nacional o que establezca que los hallazgos de objetos arqueológicos sean propiedad del Estado, sino de quien los encuentre. Existe un sistema de registro de tesoros culturales inmuebles ("monumentos antiguos", en los términos de la norma) y muebles ("antigüedades y objetos de arte"), si bien en este último caso se limita a aquellos objetos considerados de especial valor para el Estado por su interés histórico, artístico o arqueológico (sección 14). Respecto a estos bienes muebles registrados, hay que tener en cuenta lo siguiente:

\section{Sección 18}

Las antigüedades u objetos de arte que son propiedad del Estado y están bajo custodia y cuidado del Departamento de Bellas Artes son inalienables, excepto en virtud de la ley. Sin embargo, si el número de ciertas antigüedades u objetos de arte similares es excesivo, el director general podrá, sujeto a la aprobación del ministro, transferirlos por medio de una venta o intercambio en beneficio de los museos nacionales o darlos a los excavadores como recompensas o como consideración por su servicio.

Asimismo, se contempla un régimen de comunicaciones al Ministerio en el caso de transmisión de los bienes por el actual poseedor, de necesidad de reparación o alteración y permisos de construcción, pero este sistema es mucho más flexible cuando se refiere a bienes muebles. Por otro lado, el desempeño de tareas profesionales vinculadas con estos objetos como la comercialización o el paso a través del territorio han de ser también comunicados. La característica esencial de este régimen es que todas estas actividades no están prohibidas, y su ejercicio se supedita exclusivamente a la obtención de una licencia previa. Es más, se prevé que en caso de que la licencia de actividad se deniegue, el solicitante puede recurrir al ministerio (sección 19).

\section{Sección 22}

Ninguna persona podrá exportar o sacar del Reino ninguna antigüedad $\mathrm{u}$ objeto de arte, independientemente de si está registrado o no, a menos que se haya obtenido una licencia del director general.

La solicitud de una licencia y la concesión de la misma se ajustarán a las normas, procedimientos y condiciones prescritos en el Reglamento Ministerial.

Las disposiciones del párrafo uno no se aplicarán a los objetos de arte que no tengan más de cinco años de antigüedad y que no hayan sido registrados y para la traída de antigüedades $\mathrm{u}$ objetos de arte en tránsito.

\section{Sección 23}

Toda persona que desee despachar temporalmente antigüedades u objetos de arte del Reino deberá solicitar una licencia al director general. En caso de que el director general dé la orden de negarse a otorgar la solicitud, el solicitante tiene derecho a presentar un recurso de apelación contra dicha orden de denegación ante el ministro dentro de los treinta días posteriores a la fecha de conocimiento de dicha orden. La decisión del ministro será final. En caso de que el director general lo considere oportuno o el ministro decida que se expida una licencia al solicitante para el despacho temporal de antigüedades u obras de arte fuera del Reino, y el solicitante haya aceptado cumplir con las condiciones, métodos y requisitos en depósito de dinero de seguridad y/ o el pago de las sanciones según lo prescrito en el Reglamento Ministerial correspondiente, el director general otorgará una licencia temporal al solicitante.

Tailandia ha suscrito en 2000 un convenio bilateral con Camboya para combatir el tráfico ilícito de bienes culturales y favorecer su pronta restitución. Es el único país con el que Tailandia ha suscrito un acuerdo de esta naturaleza, pero tiene sentido si se recuerda que son estados colindantes y que antes de su actual delimitación fronteriza, Camboya y Tailandia constituían el Reino de Siam, hasta la expansión del colonialismo francés en el siglo XVIII, que ocupó parte de los territorios de la actual Camboya, Vietnam y Laos.

\section{Legislación de patrimonio y los acuerdos de libre comercio}

Un análisis sistemático de la legislación tailandesa pone en evidencia que, en efecto, este Estado no prohíbe la exportación de bienes culturales propios, y que da muchas facilidades para el paso a través de su territorio cuando los objetos están en tránsito. A este hecho se suman los acuerdos de libre comercio suscritos entre la UE y la ASEAN (Asociación de Naciones del Sudeste Asiático, de la que Tailandia forma parte desde su constitución en 1967). Ambas organizaciones suscribieron un acuerdo de cooperación en 1980 referido a la supresión de limitaciones al libre comercio, especialmente los obstáculos arancelarios. En 2013 se firmó el Partnership and Cooperation Agreement, PCA, pero aún está pendiente de ratificación debido al golpe de estado que tuvo lugar en Tailandia en 2014. Asimismo, cabe señalar que Tailandia forma parte de la OMC desde su creación en 1995.

$\mathrm{Si}$ bien las relaciones internacionales tienen como uno de sus principales objetivos el fomento del comercio mediante acuerdos multilaterales que favorezcan el intercambio comercial y reduzcan o supriman los aranceles aduaneros, el grado de extensión de dichos acuerdos varía sustancialmente de un país a otro. Así, mientras estas prácticas estaban ya muy avanzadas y consolidadas entre Europa y Asia, particularmente con la ASEAN, desde hace varias décadas, la situación es distinta con los países de la cuenca oriental del Mediterráneo.

Existen negociaciones y acuerdos de entendimiento entre la UE y países como Egipto, Turquía (que aspira a integrar la Unión), Líbano o Jordania; pero estos acuerdos no están concluidos, entre otras razones 
porque para su firma es imprescindible que el país forme parte de la OMC, y no todos pertenecen a la organización (por ejemplo, Líbano, que solicitó su ingreso en 1999).

Egipto, en concreto, ha suscrito acuerdos comerciales con EFTA, en vigor desde 2007, y forma parte del proceso "Unión para el Mediterráneo", que busca la asociación comercial entre la UE y el resto de países de la cuenca mediterránea, contexto precedido por algunos convenios previos, como el suscrito entre Egipto y la UE en 2001 y el acuerdo agrícola de 2010. ${ }^{84}$ Por su parte, Emiratos Árabes integra el Consejo de Cooperación del Golfo (CCG), con el que la UE firmó un acuerdo de libre comercio en 1989. Uno de los puntos clave en estas relaciones es la aplicación a los países del CCG del Sistema de Preferencias Generalizadas ${ }^{85}$ conforme al cual los productos procedentes de esta región entran en la Unión en condiciones preferentes. ${ }^{86}$ Emiratos Árabes se benefició de estas licencias hasta 2012, año en que se aprobó el Reglamento (UE) 978/2012 y se actualizaron las condiciones de aplicación en favor de los países en proceso de desarrollo, excluyendo a aquellas naciones que habían sido calificadas por el Banco Mundial como de renta alta. En consecuencia, actualmente ninguno de los países del CCG, todos ellos considerados de renta alta, se benefician del Sistema de Preferencias, pero debemos recordar que dicho sistema se refiere a la eliminación de costes arancelarios, no a los flujos de comercio que se han ido consolidando con los años y que entre la UE y el CCG son muy fluidos. ${ }^{87}$ No existe, en cambio, ningún proceso semejante con Libia, país con el que hasta el momento las negociaciones de los últimos años con la UE se han centrado en atender la crisis de los refugiados.

A su vez, hay que tener presente la agrupación comercial entre los estados integrantes de GAFTA, la Gran Zona Árabe de Libre Comercio, de la que forman parte Egipto, Jordania, Emiratos Árabes, Bahrein, Arabia Saudita, Omán, Qatar, Marruecos, Siria, Líbano, Irak, Palestina, Kuwait, Túnez, Libia, Argelia, Sudán y Yemen. Se trata de una asociación con intereses comerciales en la que se han suavizado las barreras a la libre circulación de mercancías y servicios, sin eliminar por completo los controles arancelarios, aunque se han adquirido compromisos hacia su reducción y supresión progresivas.

En este sentido, y por lo que respecta a las rutas de contrabando de bienes culturales, se entiende que es más fácil que los objetos extraídos de Libia pasen directamente a Egipto, país con el que comparte frontera, o a Jordania, y que desde allí se trasladen por mar hasta Emiratos Árabes Unidos. Posteriormente, aprovechando las ventajas aduaneras de este país

84. <http://www.comercio.gob.es/es-ES/comercio-exterior/ politica-comercial/relaciones-bilaterales-union-europea/paises-mediterraneos/Paginas/egipto.aspx $>$.

85. Generalised Scheme of Preferences (GSP).

86. <http://www.comercio.gob.es/es-ES/comercio-exterior/politica-comercial/relaciones-bilaterales-union-europea/asia/Paginas/ Emiratos-\%C3\%81rabes-Unidos.aspx>.

87. <http://ec.europa.eu/trade/policy/countries-and-regions/ regions/gulf-region/>. de la CCG, se importarían a Europa en condiciones favorables. No obstante, como hemos visto, estas condiciones de beneficio o exención aduanera han cambiado en los últimos años, y ese es el motivo por el que se comiencen a explorar otras rutas de distribución que pasan por Asia, como en el caso que ahora nos ocupa.

Lo que acabamos de exponer esboza un panorama global que los contrabandistas conocen muy bien y que tratan de aprovechar para facilitar el tráfico ilegal y llevar las piezas a destino. No obstante, se siguen acumulando errores en los documentos que se adjuntan a las declaraciones de importación, algo que solo puede detectarse por expertos y tras una investigación detallada de los expedientes. Como señala Fernando Porcel, se trata de "piezas calientes", 88 extraídas de territorios en conflicto, donde ni el comerciante de prestigio ni el coleccionista quieren verse envueltos. Por eso, el comprador final de estas piezas es totalmente ajeno a esta realidad. No así el marchante sin escrúpulos que se encuentra al final de la cadena de contrabando, que participa activamente en la trama y se encarga de limpiar el origen de los bienes bajo una apariencia de profesionalidad y seriedad comercial. Como explica Arthur Brand, un investigador que ayuda a recuperar antigüedades robadas, la facilidad de los marchantes en ofrecer piezas es asombrosa. El tráfico ilícito se reviste de una apariencia de negocio formal, con oficinas y tarjetas de visita, realmente pasmosa. La conexión entre saqueadores y marchantes es la parte verdaderamente oscura y turbia del negocio, manifiesta. ${ }^{89}$

\section{Pero ¿por qué España?}

España no parece ser el país ideal para comercializar bienes culturales saqueados, ya que la legislación despliega un sistema altamente proteccionista de estos tesoros y pone bastantes trabas a su comercialización, y más a su exportación, que en muchas ocasiones está terminantemente prohibida. Sin embargo, es necesario conocer bien la regulación para encontrar los trucos que encierra, además de entender totalmente el sistema normativo nacional de tradición romana que presenta también sus ventajas.

Conviene recordar a este respecto que el ordenamiento español protege a los adquirentes de buena fe frente a las reclamaciones de terceros, y que diseña un sistema de prescripción adquisitiva de bienes muebles que, incluso en los casos de mala fe, se cumple a los seis años, un plazo considerablemente breve. Habría que tener en cuenta aquí el delito de receptación o la participación de un encubridor, que extiende dichos plazos de usucapión (arts. 1.955 y 1.956 Código Civil). Esta tradición jurídica se aparta de la pauta del sistema de common law, que sigue la máxima nemo dat quod non habet, de modo que el vicio esencial en la transmisión impide que se pueda adquirir o traspasar la propiedad. Sin embargo, hay

88. Vid. supra "El «niño prodigio» del arte antiguo que financió a Daesh" $(A B C)$.

89. Vid. supra "The men who smuggle the loot that funds IS" (BBC News). 
que tener en cuenta que en estas tramas de comercio ilegal los traficantes hacen verdaderos esfuerzos por depurar el origen de los bienes, precisamente para hacer creer a sus compradores que el objeto tiene una procedencia lícita. De este modo, la pieza se traspasa a un comprador de buena fe y se consolida su propiedad a los tres años de posesión pública, ininterrumpida y pacífica. Por esta vía lo que se logra es hacer fracasar las reclamaciones posteriores, ya que nuestro ordenamiento protege al adquirente de buena fe.

Este es uno de los motivos por el que los traficantes tienden a introducir los bienes en el mercado a través de países cuya normativa protege al comprador de buena fe, como Italia o España, ya que de este modo se depura el tracto sucesivo y se posibilita su posterior comercialización.

Pero una venta dentro de España supone en sí mismo un peligro, ya que si el bien procede del extranjero, el Estado puede estar interesado en que permanezca en nuestro territorio debido a sus cualidades artísticas, históricas o arqueológicas. El Estado tiene potestad para iniciar de oficio el procedimiento para declarar un objeto como bien de interés cultural, lo que implica, además de registrarlo e inventariarlo, que se convierte en inexportable. Este régimen busca preservar los tesoros nacionales dentro de nuestras fronteras y evitar la fuga de riquezas, que tan lamentable y devastadora fue en épocas anteriores. Sin embargo, tiene también sus consecuencias: los bienes que no pueden abandonar el país solo pueden venderse a compradores de dentro, lo que hace que los precios de adquisición se devalúen y que el mercado español de arte y antigüedades sea endogámico y poco competitivo.

No obstante, no siempre es necesario que haya una primera transmisión en el país para que los marchantes aprovechen las ventajas normativas del sistema. La Ley de Patrimonio Histórico Español 16/1985 de 25 de junio (LPHE) concede la posibilidad de que se declare la importación de bienes culturales venidos de fuera. Se trata de una declaración potestativa, que presenta una serie de ventajas: el régimen general de la norma deja de aplicarse durante diez años (prorrogable, previa solicitud) a ese objeto (art. 32.3 LPHE). En consecuencia, no cabe una declaración de oficio como bien de interés cultural y, por lo tanto, no será inexportable. Asimismo, las prerrogativas de tanteo $\mathrm{y}$ retracto en favor del Estado en caso de venta del bien, tampoco funcionan. El único requisito es que se cumpla con la formalidad de la declaración de importación, ya que si, después de haber entrado el bien en nuestro país, se solicita un permiso de exportación y no se puede demostrar fehacientemente cuándo entró, podría denegarse la licencia.

\section{Artículo 32}

1. Los bienes muebles cuya importación haya sido realizada legalmente y esté debidamente documentada, de modo que el bien importado quede plenamente identificado, no podrán ser declarados de interés cultural en un plazo de diez años a contar desde la fecha de su importación.

2. Tales bienes podrán exportarse previa licencia de la Administración del Estado, que se concede- rá siempre que la solicitud cumpla los requisitos exigidos por la legislación en vigor, sin que pueda ejercitarse derecho alguno de preferente adquisición respecto de ellos. Antes de que finalice el plazo de diez años los poseedores de dichos bienes podrán solicitar de la Administración del Estado prorrogar esta situación, que se concederá siempre que la solicitud cumpla los requisitos exigidos por la legislación en vigor y oído el dictamen de la Junta de Calificación, Valoración y Exportación de Bienes del Patrimonio Histórico Español.

\section{[...]}

Por otro lado, declarar la importación de bienes culturales presenta también ventajas fiscales. De acuerdo con el art. 30.B).1. LPHE están exentas de pagar la tasa por la autorización de exportación las salidas de bienes importados en los términos del art. 32, es decir, la exportación de los objetos cuya importación se hubiese declarado debidamente. De esta forma, declarar la importación le asegura al marchante que podrá volver a sacar el bien del país y que no tendrá que pagar una tasa para obtener la preceptiva licencia de exportación.

La razón de ser de este régimen de excepción reside en la propia esencia de la LPHE: el sistema trata de proteger los monumentos y objetos que han estado en las colecciones y museos del país largo tiempo, y que se consideran ya integrantes del patrimonio cultural nacional. El plazo de diez años está puesto para generar una mínima relación temporal con nuestro territorio antes de entender que el bien puede calificarse como parte de nuestro patrimonio cultural. Recordemos que no es imprescindible que esos bienes estén vinculados con la historia de España ni hayan sido creados en España o elaborados por artistas españoles. Por este motivo, muchos marchantes realizan estas declaraciones con la intención fundamental de posibilitar una fácil salida del bien de nuestro territorio en el momento en que se quiera comercializar fuera, cosa que es habitual, habida cuenta de la buena salud de algunas plazas de antigüedades europeas en comparación con nuestro mercado nacional. Este es sin duda el caso del anticuario barcelonés y su táctica, llevando las obras a ferias como Brafa, en Bruselas, donde atraían el interés de numerosos compradores extranjeros que elevaban el precio de cotización.

Fue el análisis de esas declaraciones de importación y su aumento lo que estrechó el cerco en torno a este anticuario. La escasez de piezas lícitas disponibles en el mercado procedentes de Cirene se contradice con el número de solicitudes cursadas. Además, había contradicciones entre el país de origen declarado y el lugar de emisión de las facturas, sumado al hecho de que la legislación de estos países prohíbe la exportación de bienes culturales, como ya hemos visto.

La praxis profesional observada habitualmente en este sector plantea serios problemas en la lucha contra el expolio y el tráfico de antigüedades. Recordemos que la mayoría de los marchantes no solicita prueba documental del origen declarado de los objetos que compran a sus proveedores y dice confiar en las declaraciones de origen y procedencia que aseveran sus colegas de profesión, sustentando sobre esa base su 
buena fe. No obstante, esta conducta se aviene mal con las nuevas exigencias del mercado. Los tratados internacionales sobre restitución exigen una diligencia cualificada en los compradores para demostrar la concurrencia real de buena fe, y la Directiva 2014/60/ UE invierte la carga de la prueba, de modo que ha de ser el adquirente quien demuestre que puso toda la diligencia posible para cerciorarse de la legalidad de la pieza. Entre los elementos tomados en cuenta para apreciar diligencia y buena fe se mencionan la consulta de bases de datos públicas sobre obras robadas o en peligro, o la comparación de precios de mercado para objetos similares que no despierten sospechas fundadas sobre la ilegalidad del bien. A este respecto, Walid Abuabdalla, encargado de negocios de la embajada libia en España, señala que no resulta verosímil que un reputado anticuario no crea sospechoso que le ofrezcan una pieza de 3.000 años de antigüedad por solo $2.000 \$$, ni que no se muestre alarmado por las marcas de una extracción apresurada y forzosa que eran tan evidentes..$^{90}$

\section{Reacción de la comunidad internacional frente al expolio masivo del patrimonio}

El caso abierto en España es un excelente testimonio de cómo funcionan las redes de tráfico ilícito de antigüedades y cómo los bienes culturales se ven expuestos a multitud de peligros, especialmente en situaciones de conflicto armado y de inestabilidad política. Estamos ante un viejo problema que ha sabido adaptarse a los nuevos tiempos y aprovechar los subterfugios legales para abrirse camino. La siempre difícil tensión entre la demanda de bienes escasos y el deseo de riqueza lleva a la creación y mantenimiento de estas tramas dedicadas al expolio y el abastecimiento de tesoros culturales. Según datos de la UNESCO, el tráfico ilícito de antigüedades es uno de los mercados ilegales más persistentes, junto con el de drogas y el de armas (UNESCO 2011: 3). La doctrina ha estudiado en profundidad las características de esta problemática durante décadas, ${ }^{91}$ pero la realidad llega a superar muchas veces cualquier escenario teórico construido sobre la base de casos anteriores. El panorama actual, íntimamente conectado a la eclosión de conflictos armados en países con estructuras políticas debilitadas, presenta numerosos retos y pone a la comunidad internacional en un brete ante la imposibilidad de hacer frente a los ataques que hemos presenciado en los últimos años. No obstante, el tráfico ilícito de bienes culturales es un problema mundial que solo puede combatirse con cooperación entre países. Las principales organizaciones internacionales se han pronunciado en numerosas ocasiones a este respecto con un mensaje unánime de rechazo y llamamiento a la colaboración.

En relación con el reciente conflicto en Oriente Medio, la consciencia internacional del peligro al que

90. Vid. supra "De los anticuarios de lujo a las arcas del terrorismo islamista” (El País).

91. Véase Dietzler (2013). estaban expuestos los yacimientos situados en las zonas ocupadas hizo que la UNESCO, bajo el auspicio de la UE, organizase un proyecto de salvaguardia del patrimonio cultural sirio que comenzó a funcionar el 1 de marzo de 2014 y tenía una duración de tres años. ${ }^{92} \mathrm{~A}$ este proyecto siguieron otras campañas de concienciación internacional a iniciativa de este organismo como \#Culture4heritage.

Por su parte, el Consejo de Seguridad de la ONU aprobó el 12 de febrero de 2015 la Resolución $2199^{93}$ prohibiendo la comercialización de, entre otras cosas, antigüedades procedentes de Siria e Irak para no contribuir a la financiación de los grupos terroristas. En diciembre de ese mismo año se adoptó la Resolución 2253 con el fin de instar a los países miembros a cumplir los postulados de la precedente resolución. Paralelamente, el Parlamento Europeo aprobaba la Resolución 2015/2649 de 12 de abril de $2015^{94}$ sobre la destrucción de patrimonio cultural llevada a cabo por ISIS, haciendo un llamamiento a la cooperación internacional para luchar contra estas prácticas.

Poco después de estas resoluciones, el septiembre de 2016 recayó la histórica condena de la Corte Penal Internacional por crímenes de guerra después de que Al Mahdi hubiese ordenado la destrucción de varios templos en Tombuctú pertenecientes al patrimonio cultural de Mali. Este país estaba inmerso en un cruento conflicto bélico en el que se sucedieron varios grupos terroristas, el último de ellos el yihadista encabezado por el condenado. El precedente inmediato de este fallo judicial estaba en los delitos cometidos en la antigua Yugoslavia, aunque no se había valorado de forma aislada la destrucción del patrimonio como un crimen contra la humanidad, sino en conjunto con otras acciones bélicas. Ahora, el ataque intencional a los tesoros culturales se estimaba un crimen de guerra (Gutiérrez Zarza 2017: 8). En este contexto, y habiendo estallado ya el conflicto en Siria, la entonces directora general de la UNESCO, Irina Bokova, declaró en relación con los atentados que destruyeron Nimrud, en Irak, que "la destrucción deliberada del patrimonio cultural constituye un crimen de guerra".$^{95}$

Esta respuesta internacional condenatoria, no obstante, seguía siendo insuficiente. Las imágenes por satélite de los territorios en conflicto ponían de manifiesto que se había procedido al expolio indiscriminado de bienes culturales, sin embargo, su rastreo en el mercado no da cuenta del volumen de objetos que deberían estar en circulación. El 24 de marzo de 2017, la ONU aprobó una nueva resolución, la $2347,{ }^{96}$ en la que se condena abiertamente el expolio del patrimonio cultural y urge a todos los países a que adopten medidas para combatirlo, prevenirlo y evitarlo, con especial énfasis en las actividades lle-

92. "The Emergency Safeguarding of the Syrian Cultural Heritage project", web oficial de la UNESCO.

93. <https://www.un.org/sc/suborg/en/node/5248>.

94. <http://www.europarl.europa.eu/sides/getDoc.do?type $=$ TA\&reference $=$ P8-TA-2015-0179\&language $=\mathrm{EN}>$.

95. Ver declaración completa del 06/03/2015 en <https://whc. unesco.org/en/news/1244>.

96. <https://www.unodc.org/documents/organized-crime/ mandates_on_trafficking_in_cultural_property/ resolution_2347/ N1707909_S.pdf>. 
vadas a cabo por grupos terroristas como forma de financiación.

La doctrina ha puesto de manifiesto que, hasta tiempos recientes, la labor de lucha contra el tráfico ilícito llevada a cabo por organismos como UNESCO, Unidroit, Interpol, UNODC, ICOM y otros se había centrado en el diseño de acciones preventivas, pero no existía una buena coordinación entre las autoridades judiciales ni una persecución penal efectiva de estas conductas (Gutiérrez Zarza 2017: 4). Algunos autores señalan que la constatación de que el tráfico de antigüedades está conectado con otras formas de crimen organizado, como el terrorismo en el caso de DAESH, puede llevar a desarrollar políticas de legislación criminal más efectivas para combatirlo (Dietzler 2013: 339).

El último avance a este respecto ha sido el Reglamento (UE) 2019/880 del Parlamento Europeo y del Consejo, de 17 de abril de 2019, relativo a la introducción y la importación de bienes culturales. Esta norma prohíbe la importación de bienes culturales que hayan salido ilícitamente de sus países de origen, especialmente cuando provengan de territorios en conflicto y su comercialización pueda servir para financiar el terrorismo. El reglamento hace una clasificación de los bienes por categorías en atención a su importancia. El objetivo es homogeneizar los procedimientos de importación de los distintos estados miembros para que las respectivas unidades aduaneras estén en disposición de bloquear la entrada de dichos bienes en el territorio de la Unión.

El Reglamento (UE) 2019/880 es el resultado de un conjunto de decisiones, informes y normas previas en las que la Unión Europea ha manifestado su compromiso de luchar contra las formas de financiación del terrorismo y el blanqueo de capitales, donde los bienes culturales eran usados con fines instrumentales. Asimismo, el preámbulo insiste en la necesidad de prestar especial atención al funcionamiento de los puertos francos, para que no se conviertan en lugares que eludan la aplicación de esta normativa. El conjunto de disposiciones del reglamento trata de buscar un justo equilibrio entre el comercio legal de bienes culturales y las prácticas ilícitas que se aprovechan de la falta de uniformidad en los procedimientos aduaneros de importación.

Esta norma merece una valoración positiva, ya que, hasta el momento, la lucha contra el tráfico ilícito de bienes culturales se encauzaba como un tipo de delincuencia complementaria de otras formas de crimen organizado, pero escasamente había atraído atención por sí mismo. La expansión incontrolada del expolio en zonas de conflicto y la progresiva importancia reconocida al patrimonio cultural en el contexto internacional explican en gran medida este cambio en la manera de afrontar el problema. Más allá de las recomendaciones y la condena pública del saqueo, es necesario atacar las rutas de comercialización de estos bienes y sus vías de entrada en los principales mercados occidentales, especialmente Europa. Este planteamiento explica la afirmación contenida en el preámbulo del Reglamento: "El comercio ilícito de bienes culturales contribuye en muchos casos a una homogeneización cultural forzosa o a la pérdida for- zosa de la identidad cultural, mientras que el saqueo de bienes culturales conduce, entre otras cosas, a la desintegración de las culturas. Mientras sea posible participar en un comercio lucrativo de bienes culturales excavados ilícitamente y obtener beneficios de dicho comercio sin grandes riesgos, tales excavaciones y saqueos seguirán produciéndose".

Aún es pronto para valorar el impacto de esta norma y su eficacia en la lucha contra el tráfico ilícito de bienes culturales, entre otras cuestiones porque el reglamento prevé la creación de una base de datos centralizada de objetos importados que no será implementada hasta 2025; pero algunos profesionales del sector ya han manifestado su preocupación de que dichas disposiciones vayan a perjudicar el negocio, impongan excesivos trámites y disuadan a potenciales compradores. ${ }^{97}$

\section{Qué sabemos y qué no sabemos sobre el comercio de antigüedades por DAESH: conclusiones}

Aunque son muchas las cifras de negocio difundidas en los medios de comunicación, las listas de yacimientos expoliados, las estimaciones de piezas saqueadas y la aseveración de que el tráfico de bienes culturales es una de las principales fuentes de financiación de este grupo terrorista, no faltan voces que piden un poco de cautela a la hora de dar por válidas estas afirmaciones mientras se espera por más indicios.

En la causa abierta en España, Fernando Porcel indicaba que hacer el seguimiento del dinero no era sencillo. Se habían registrado pagos en efectivo e ingresos en cuentas que parecen vinculadas al grupo, pero la investigación aún debe arrojar más resultados.

De acuerdo con los testimonios de los marchantes que dicen haber trabajado para DAESH, el grupo se financia mediante el cobro de una tasa por la concesión de las licencias de excavación. Esto parece concordar con los documentos oficiales emitidos por el instaurado Departamento de Recursos Naturales y su División de Antigüedades, del autoproclamado califato, que prohíbe la exportación de bienes arqueológicos e históricos y exige la obtención de una licencia para excavar en los yacimientos. Asimismo, parece concordar con los datos contenidos en la documentación requisada a Abu Sayyaf, según la cual figuran ingresos de $265.000 \$$ por impuestos relacionados con las antigüedades, como señala el informe de la policía neerlandesa. ${ }^{98} \mathrm{El}$ propio informe estima que no hay aún pruebas suficientes para considerar probada esta conexión.

Por otro lado, varios académicos señalan que el problema del tráfico ilícito de bienes culturales ya existía en muchos territorios antes de ser ocupados

97. Véase "Tick tock: Regulations on the import of non-EU-cultural goods are now in effect. How will this affect the international art market?" publicado en Winterworldwide el 27/06/2019; y "Trading in Antiquities" de Gregor Kleinknecht publicado en Hunterslaw el 15/08/2019.

98. Vid. supra informe "Cultural Property War Crimes and Islamic State". 
por el DAESH y que su propagación no se puede atribuir exclusivamente a su presencia en el lugar. Roslington y Pack, entre ellos, aclaran que, aunque los medios occidentales así lo hayan difundido, no hay suficientes evidencias de que DAESH se financie mediante la comercialización de objetos arqueológicos. El vandalismo y el expolio en Libia existían desde antes de que el grupo entrase en la región y ocupase Sabratha desde diciembre de 2015, y no hay constancia de que hayan invadido otros yacimientos. ${ }^{99} \mathrm{En}$ esta misma línea se desarrolla el trabajo del grupo MANTIS de la Universidad de Chicago, al que ya hemos aludido. Por último, traemos a colación las consideraciones de Morgan Belzic, que insiste en que son los investigadores quienes deben establecer esa conexión entre el comercio de antigüedades y la financiación terrorista, pero en su opinión sería un error ceñirse exclusivamente a este aspecto, porque DAESH ya no está en Libia, como tampoco en Irán, y, sin embargo, el tráfico ilícito sigue existiendo. ${ }^{100}$

No obstante, conviene tener presente que según el testimonio de los saqueadores y marchantes entrevistados, la forma de obtener recursos por el DAESH ha cambiado. Si bien inicialmente obtenían ingresos mediante el pago de una tasa por la concesión de licencias de excavación, parece que con el tiempo eran ellos mismos quienes compraban las piezas a los saqueadores para hacerse cargo directo de su venta.
Este cambio de práctica parece coincidir con la época en que sus fuerzas son duramente atacadas y se ven obligados a replegarse. Quizás en este punto es cuando comiencen a usar las antigüedades como elemento de intercambio para obtener armas y munición, algo que también puede deberse a la iniciativa de alguna unidad en particular y en una zona concreta, por razón de sus conexiones internacionales singulares.

Seguiremos a la espera de que la investigación en España arroje resultados concluyentes al respecto y permita o no establecer un nexo directo entre el tráfico de bienes culturales y la financiación del terrorismo. Mientras esto no se demuestre, parece que el saqueo y contrabando de antigüedades es, como siempre ha sido, una práctica deplorable que aprovecha en cada momento las condiciones favorables que el contexto histórico, social y político le ofrece. En lo que al DAESH se refiere, es evidente que la inestabilidad y la escasez de recursos económicos son el mejor combustible para alimentar una conducta ilegal que puede reportar grandes beneficios. Pero también es paradigmático que toda la gente entrevistada señale al grupo terrorista responsable del expolio, pero ninguno de ellos pertenezca a la organización. ¿Será que las tramas preestablecidas no han hecho sino cambiar de dirigentes y arrimarse al sol que más calienta? ¿Estamos ante una simple continuidad de prácticas heredadas? Algo así resultaría mucho más coherente con los documentos y testimonios recabados hasta el momento.
Marta Suárez-Mansilla

Data de recepció: 19/08/2019 Data d'acceptació: 12/11/2019

99. "Who Pays for ISIS in Libya?" publicado en Hate Speech el $24 / 08 / 2016$.

100. "Trafic d'art démantelé en Espagne: «Mes recherches m'ont convaincu que j'étais face à un trafic»", publicado en Paris Match el 29/03/2018. 


\section{Artículos}

Ali, C. (2013). Syrian Heritage under Threat. Journal of Eastern Mediterranean Archeology \& Heritage Studies 1, no. 4 (2013): 351-366. <https://www.jstor. org/stable/10.5325/jeasmedarcherstu.1.4.0351\#fndtnfull_text_tab_contents>.

Blannin, P. (2017). Islamic State's Financing: Sources, Methods and Utilisation. Counter Terrorist Trends and Analyses, Vol. 9, No. 5 (May 2017): 13-22. <https:// www.jstor.org/stable/10.2307/26351519>.

Belzic, M. (2017). Les sculptures funéraires de Cyrénaïque sur le marché de l'art. Lybian Studies, vol. 48, November 2017: 105-116. <https://doi.org/10.1017/ lis.2017.12>.

Brennan, K. y Fitz Gibbon, K. (2017). Bearing False Witness: The Media, ISIS and Antiquities. A Special Report from the Committee for Cultural Policy. $<$ https:// culturalpropertynews.org/wp-content/uploads/2017/12/ CCP-Bearing-False-Witness-The-Media-ISIS-and-Antiquities-1.pdf $>$.

Campbell, P. B. (2013). The Illicit Antiquities Trade as a Transnational Criminal Network: Characterizing and Anticipating Trafficking of Cultural Heritage. International Journal of Cultural Property (2013), 20: 113-153.

Casana, J. (2015). Satellite Imagery-Based Analysis of Archaeological Looting in Syria. Near Eastern Archaeology, Vol. 78, No. 3, Special Issue: The Cultural Heritage Crisis in the Middle East (September 2015): 142-152. <https://www.jstor.org/stable/pdf/10.5615/neareastarch.78.3.0142.pdf $>$.

Casana, J. y Laugier, E. J. (2017). Satellite imagerybased monitoring of archaeological site damage in the Syrian civil war. PLoS ONE, 12(11).

Cengiz, M. (2017). The Trafficking of Turkish and Syrian Antiquities. <http://traccc.gmu.edu/wp-content/ uploads/2017/05/THE-TRAFFICKING-OF-TURKISHAND-SYRIAN-ANTIQUITIES.pdf>.

Danti, M.; Branting, S. y Penacho, S. (2017). The American Schools of Oriental Research Cultural Heritage Initiatives: Monitoring Cultural Heritage in Syria and Northern Iraq by Geospatial Imagery. Geosciences, 2017, 7, no 4: 95. <http://www.mdpi. com/2076-3263/7/4/95>.

Dieltzler, J. (2013). On 'Organized Crime' in the illicit antiquities trade: moving beyond the definitional debate. Trends in Organized Crime. Springer (2013), 16: 329-342. <https://www.ncbi.nlm.nih.gov/pmc/articles/ PMC4730908/\#CR31>.
Fernández Liesa, C. R. (2009). Evolución jurídica de la protección internacional de los bienes culturales en los conflictos armados. Anuario Español de Derecho Internacional, vol. XXV: 239-262.

Gutiérrez Zarza, Á. (2017). Ponencia “Tráfico ilícito de bienes culturales y cooperación penal europea e internacional. En: Delitos contra el patrimonio histórico. Especial referencia al patrimonio arqueológico, 29 y 30 de junio de 2017. <https://bit.ly/2yw8Q0K>.

HenCKAERTs, J.-M. (1999). Nuevas normas para la protección de los bienes culturales en caso de conflicto armado: la importancia del segundo protocolo de la Convención de la Haya de 1954 para la protección de los bienes culturales en caso de conflicto armado. En: Protección de los bienes culturales en caso de conflicto armado. Reunión de expertos, Servicio de asesoramiento en Derecho internacional humanitario, CICR, Ginebra, octubre de 2000, 2002: 27-56. <https://www.icrc.org/es/doc/resources/documents/ misc/5tdnnb.htm $>$.

Howard, R. D.; Elliott, M. D. y Prohov, J. R. (2016). IS and Cultural Genocide: Antiquities Trafficking in the Terrorist State. Joint Special Operations University, Report 16-11.

Howard, R. D.; Elliott, M. D. y Prohov, J. R. (2015). Digging In and Trafficking Out: How the Destruction of Cultural Heritage Funds Terrorism. CTC Sentinel, febrero 2015, vol. 8, Issue 2: 14-18. <https://ctc.usma.edu/ app/uploads/2015/02/CTCSentinel-Vol8Issue27.pdf>.

Michel, V. (2014). El patrimonio libio, en peligro. Afkas/Ideas, autum 2014: 72-74. <http://www.iemed. org/observatori/arees-danalisi/arxius-adjunts/afkar/ afkar-ideas-43/afkar43_Vicent_Michel_patrimonio_Libia_es.pdf $>$.

O'Connell, M. E. (2004). Occupation Failures and the Legality of Armed Conflict: The Case of Iraqi Cultural Property. Art Antiquity and Law, vol. 9, no. 4, December 2004: 323-362.

Shelley, L. I. (2014). Dirty Entanglements: Corruption, Crime, and Terrorism. Cambridge University Press. Nueva York.

SuÁrez-Mansilla, M. (=González-Suárez, M.) (2018). Restitution of Cultural Heritage in the European Directives: Towards and Enlargement of the Concept of 'Cultural Goods. Art, Antiquity and Law, vol. XXIII, issue 1, abril 2018: 1-27.

UNESCO (2011). La lucha contra el tráfico ilícito de objetos culturales la convención de 1970: pasado y futuro. Carpeta informativa. UNESCO. París. 


\section{Webgrafía}

\section{Webs oficiales}

\section{UNESCO}

- "The Emergency Safeguarding of the Syrian Cultural Heritage project": <https://en.unesco.org/ syrian-observatory/emergency-safeguarding-syriancultural-heritage-project>.

-UNESCO Director General condemns destruction of Nimrud in Iraq, publicado el 06/03/2015 < https:// whc.unesco.org/en/news/1244>.

\section{COMISIÓN EUROPEA}

-Generalised Scheme of Preferences (GSP) <http:// ec.europa.eu/trade/policy/countries-and-regions/ development/generalised-scheme-of-preferences/ index_en.htm $>$.

— $<$ http://ec.europa.eu/trade/policy/countries-andregions/regions/gulf-region/>.

SECRETARÍA DE ESTADO DE COMERCIO. MINISTERIO DE ECONOMÍA, INDUSTRIA Y COMPETITIVIDAD DE ESPAÑA

— <http://www.comercio.gob.es/es-ES/comercio-exterior/politica-comercial/relaciones-bilaterales-unioneuropea/paises-mediterraneos/Paginas/egipto.aspx $>$.

- <http://www.comercio.gob.es/es-ES/comercio-exterior/ politica-comercial/relaciones-bilaterales-union-europea/asia/Paginas/Emiratos-\%C3\%81rabes-Unidos. aspx $>$.

\section{Webgrafía (por orden de cita en el texto)}

“ISIS' looting of the Middle East is 'the largest-scale mass destruction of cultural heritage since' WWII", publicado en Business Insider por Pamela Engel el 12/01/2016. <https://www.businessinsider.com/isisantiquities-destroyed-smuggling-2016-1 ? IR=T $>$.

"ISIS diversifica sus fuentes de ingresos para superar la dependencia del crudo" publicado en eldiario.es el 12/12/2015 <https://www.eldiario.es/economia/solopetroleo-formas-financiacion-ISIS_0_458454357.html>.

"Calculating the Revenue From Antiquities to Islamic State", artículo de Duncan Mavin, publicado en The Wall Street Journal el 11/02/2015 <https://www.wsj. com/articles/calculating-the-revenue-from-antiquitiesto-islamic-state-1423657578>.

"How ISIS turns artifacts into cash", reportaje de Drew Griffin para la CNN publicado el 11/12/2015 $<$ https:/edition.cnn.com/videos/world/2015/12/12/isisartifact-financing-griffin-pkg-ac.cnn>.

"ISIS is making $\$ 200$ million from stolen ancient artifacts", publicado en Business Insider el 06/04/2016: <http://www.businessinsider.com/r-islamicstate-nets-up-to-200-million-a-year-from-antiquitiesrussia-2016-4>.

"Conflict and the Heritage Trade: Rise in U.S. Imports of Middle East "Antiques" and "Collectors' Pieces" Raises Questions", publicado en Cultural Heritage Lawyer el 06/10/2014 <https://culturalheritagelawyer. blogspot.com/2014/10/conflict-and-heritage-trade-risein-us.html>.

"AAAS Analysis Shows Widespread Looting and Damage to Historical Sites in Syria”, publicado el 17/12/2014 $<$ https://www.aaas.org/news/aaas-analysis-showswidespread-looting-and-damage-historical-sites-syria $>$.

“'Ancient statues' destroyed by ISIS in Mosul were FAKES - and the originals are safely stored in Baghdad, claims Iraqi museum director" en Daily Mail 16/03/2015: <http://www.dailymail.co.uk/news/ article-2996859/Ancient-statues-destroyed-ISIS-MosulFAKES-originals-safely-stored-Baghdad-claims-Iraqimuseum-director.html>.

Andrew Keller: “Documenting ISIL's Antiquities Trafficking: The Looting and Destruction of Iraqi and Syrian Cultural Heritage: What We Know and What Can Be Done" publicado el 29 de septiembre de 2015 <https://2009-2017.state.gov/e/eb/rls/rm/2015/ 247610.htm $>$.

"Arte antica in cambio di armi, affari d'oro in Italia per l'asse fra Isis e 'ndrangheta", publicado en La Stampa el 16/10/2016: <http://www.lastampa.it/2016/10/16/esteri/ arte-antica-in-cambio-di-armi-affari-doro-in-italia-perlasse-fra-isis-e-ndrangheta-x9uX3cnjg6B3BhbIe4nTKK/ pagina.html>.

"The Men Who Trade ISIS Loot" publicado en The Wall Street Journal el 06/08/2017 <https:/www.wsj. com/articles/the-men-who-trade-isis-loot-1502017200>.

"Antiquities looted by Islamic State turn up on eBay" publicado en The Times el 14/03/2015 <https://www. thetimes.co.uk/article/antiquities-looted-by-islamicstate-turn-up-on-ebay-v29w5qjtqwq>.

"A la venta en Facebook: antigüedades robadas en Medio Oriente" publicado en The New York Times el 13/05/2019 <https://www.nytimes.com/es/2019/05/13/ antiguedades-robadas-facebook/>.

"The men who smuggle the loot that funds IS" publicado en BBC News el 17/02/2015 <http://www. bbc.com/news/magazine-31485439>.

"Meet the "Monuments Men" Risking Everything to Save Syria's Ancient Treasures From ISIS” reportaje de Bryan Schatz publicado en Mother Jones el 06/03/2015 <https:/www.motherjones.com/politics/2015/03/howisis-cashes-illegal-antiquities-trade/>.

"Save our stones", publicado en The Economist el 13/06/2015 <https://www.economist.com/news/middleeast-and-africa/21654065-well-killing-people-islamicstate-smashing-up-ancient-works-art-only>.

"Islamic State: Looting for Terror", es el reportaje de Simon Cox en File on 4 de la BBC Radio 4, emitido el 17 de febrero de 2015: <https:/www.bbc.co.uk/ programmes/b052j57v>.

"Inside the Underground Trade to Sell Off Syria's History”, publicado en BuzzFeed News, el 30/07/2015: 
$<$ https://www.buzzfeed.com/mikegiglio/the-tradein-stolen-syrian-artifacts?utm_term =.nxKkpr32q\#. ba0djlLJr>.

"ISIS Is Selling Syria's Antiquities to the West" WSJ video broadcasted on 31st May, $2015<$ https://www. wsj.com/video/isis-is-selling-syria-antiquities-to-thewest/78B1261D-3E0C-4513-8F81-5E51568B8809.html>.

"Antiquities experts call for war on Isis looting in Syria and Iraq" reportaje de Bel Trew publicado en The Times el 12/08/2017 <https://www.thetimes.co.uk/ article/antiquities-experts-call-for-war-on-isis-looting3xz5d59lt>.

"Countering is's theft and destruction of Mesopotamia", reportaje de Mark V. Vlasic y Helga Turku publicado en World Policy el 07/07/2015 <https://worldpolicy. org/2015/07/07/countering-iss-theft-and-destruction-ofmesopotamia/>.

"How an arrest in Iraq revealed Isis's \$2bn jihadist network" reportaje de Martin Chulov publicado en The Guardian el 15/06/2014 <https://www.theguardian. com/world/2014/jun/15/iraq-isis-arrest-jihadists-wealthpower>.

"ISIS' Antiquities Sideline", artículo de Amr Al-Azm, Salam Al-Kuntar y Brian I. Daniels publicado en The New York Times el 02/09/2014 <https://www.nytimes. com/2014/09/03/opinion/isis-antiquities-sideline.html>.

"Al-Rikaz Department Of ISIS Licenses Excavation Works In Exchange For Monetary Percentage", publicado en RFS Media Office el 11/03/2016 <https:// rfsmediaoffice.com/en/2015/04/23/al-rikaz-departmentof-isis-licenses-excavation-works-in-exchange-formonetary-percentage/>.

"How antiquities are funding terrorism" publicado en el Financial Times el 29/06/2015 <https://www.ft.com/ content/fbecb8a2-09df-11e5-a6a8-00144feabdc0>.

“German Media May Corroborate \$36M Islamic State Antiquities Trafficking" de San Hardy, publicado en Hyperallergic el 28/11/2014 <http://web. archive.org/web/20161228003132/http://hyperallergic. com/165537/german-media-corroborates-36m-islamicstate-antiquities-trafficking/>.

"Danti's Inference: The Known Unknowns Of ISIS and Antiquities Looting", publicado por Jason Felch en su blog Chasing Aphrodite el 18/11/2014 <https:// chasingaphrodite.com/2014/11/18/dantis-inference-theknown-unknowns-of-isis-and-antiquitieslooting/> .

"The 'Islamic State' and the illegal Sale of Antiquities", publicado en Abu Susu's Blog el 04/12/2014 <http:// abususu.blogspot.com/2014/12/the-islamic-state-andillegal-sale-of.html> .

"Antiquities: The spoils of war" de Georgina Adams, publicado en el Financial Times el 11/03/2016 <https://www.ft.com/content/950b8740-e1f6-11e5-92176ae3733a2cd1\#axzz4JnFjtNbK>.
Informe "Cultural Property War Crimes and Islamic State", septiembre 2016. <http://iadaa.org/wp-content/ uploads/2016/05/Cultural-Property-War-crimes-andIslamic-State-2016.pdf>.

"Tax and spend: laissez-faire Islamic State capitalism for the illicit antiquities trade?", publicado por Sam Hardy en su blog Conflict Antiquities el 05/12/2014 $<$ https://conflictantiquities.wordpress.com/2014/12/05/ iraq-syria-islamic-state-capitalism-looting-smugglingtaxation/>.

"Antiquities Dealer Sues Wall Street Journal Over ISIS Article", publicado en The New York Times el 17/07/2017 <https://www.nytimes.com/2017/07/17/arts/ design/antiquities-dealer-sues-wall-street-journal-overisis-article.html>.

"Islamic State is selling looted Syrian art in London to fund its fight" publicado en The Washington Post el 25/02/2015 <https://www.washingtonpost.com/ world/is-looted-syrian-art-showing-up-in-london-tofund-activities/2015/02/25/785ab630-bcd0-11e4-b274e5209a3bc9a9_story.html>.

"The ISIS' files" publicado en The New York Times el 04/04/2018 <https://www.nytimes.com/ interactive/2018/04/04/world/middleeast/isis-documentsmosul-iraq.html>.

Imágenes de "The ISIS's files" <https://www.nytimes. com/interactive/2018/04/04/world/middleeast/isisdocuments-photos.html>.

Página del proyecto de la Universidad George Washington: <https://lai.gwu.edu/archiving-terror-isisfiles $>$.

"The Archivist: Unseen Documents from the Islamic State's Diwan al-Rikaz", por Aymenn Jawad AlTamimi, publicado el 12 de octubre de 2015: <http:// www.rubincenter.org/2015/10/the-archivist-unseendocuments-from-the-islamic-states-diwan-al-rikaz/>.

"The Archivist: 26 Unseen Islamic State Administrative Documents: Overview, Translation \& Analysis" por Aymenn Jawad Al-Tamimi, publicado el 24 de agosto de $2015<$ http://www.aymennjawad.org/17757/thearchivist-26-unseen-islamic-state $>$.

"Looted in Syria - and sold in London: the British antiques shops dealing in artefacts smuggled by Isis", publicado en The Guardian el 31/07/2015 <https:// www.theguardian.com/world/2015/jul/03/antiquitieslooted-by-isis-end-up-in-london-shops $>$.

"Inside ISIS' looted antiquities trade", publicado en The Conversation el 31/06/2016 <https://theconversation. com/inside-isis-looted-antiquities-trade-59287>.

Reportaje de John Wilson para BBC Sounds: <https:// www.bbc.co.uk/sounds/play/b04n695f>.

"Illegal chains which mirror legal ones and function in the penumbra of the legal ones", publicado en 
ARCA Blog el 30/03/2018 <http://art-crime.blogspot. com.es/2018/03/>.

"Jaume Bagot, el anticuario del expolio libio descubierto por un estudiante belga", publicado en Cadena Ser el 28/03/2018 <http://cadenaser.com/ser/2018/03/28/ tribunales/1522256076_610186.html>.

"La Policía desmantela una red que comerciaba con obras de arte expoliadas en Libia que servían para financiar el terrorismo yihadista", publicado en la web oficial del Ministerio del Interior de España, 28/03/2018: <http:// www.interior.gob.es/noticias/detalle/-/journal_content/56_ INSTANCE_1YSSI3xiWuPH/10180/8548028/>.

"Jaque a las antigüedades de sangre", publicado en el $A B C, 01 / 04 / 2018$ : <http://www.abc.es/espana/abci-jaqueantiguedades-sangre-201803281319_noticia.html>.

"El «niño prodigio» del arte antiguo que financió a Daesh", publicado en $A B C, 01 / 04 / 2018$ : <http://www. abc.es/espana/abci-nino-prodigio-arte-antiguo-financiodaesh-201804010202_noticia.html>.

"Nunca en la vida he comprado piezas de Irak, Libia o Siria”, publicado en Crónica Global, 30/03/2018: <https:// cronicaglobal.elespanol.com/vida/nunca-compradopiezas-irak-libia-siria_130901_102.html>.

"De los anticuarios de lujo a las arcas del terrorismo islamista", publicado en El País, 04/05/2018: <https:/elpais.com/cultura/2018/05/04/ actualidad/1525430313_986732.html>.

"Encuentro internacional para el desarrollo" de 27 y 28 de noviembre 2018, disponible en <https://www. youtube.com/watch?v=bRqGbI9ddhM $>$.

"Libia: a rischio anche decine di tesori archeologici, stilata la "red list»", publicado en Corriere della Sera el 04/03/2016 <https://www.corriere.it/esteri/16_marzo_04/ libia-rischio-anche-decine-tesori-archeologici-stilata-redlist-850e8068-e1e2-11e5-b31b-034bb632a08d.shtml>.

"Who Pays for ISIS in Libya?" publicado en Hate Speech el 24/08/2016: <https:/www.hate-speech.org/ who-pays-for-isis-in-libya/>.

“Trafic d'art démantelé en Espagne: «Mes recherches m'ont convaincu que j'étais face à un trafic»", publicado en Paris Match el 29/03/2018: <https://parismatch. be/actualites/132073/exclusif-trafic-dart-demantele-enespagne-recherches-interview $>$.

“Tick tock: Regulations on the import of non-EU-cultural goods are now in effect. How will this affect the international art market?" publicado en Winterworldwide el 27/06/2019 <https://www.withersworldwide.com/ en-gb/insight/tick-tock-regulations-on-the-import-ofnon-eu-cultural-goods-are-now-in-effect-how-will-thisaffect-the-international-art-market $>$.

"Trading in Antiquities" de Gregor Kleinknecht publicado en Hunterslaw el 15/08/2019 <https://www. hunterslaw.com/gregor-kleinknecht-discusses-trading- in-antiquities-in-discover-germanys-september-2019issue/>.

\section{Audiovisuales}

Brems, P. y Van den Eynde, W. (2009). Blood Antiques, Thames Ditton, Surrey, England: Journeyman Pictures, DVD, 47 min. <https://www.journeyman.tv/film/4571/ blood-antiques $>$.

\section{Normas citadas \\ Documentos oficiales}

Resolución ONU S/RES/2199 (2015): <https://www. un.org/sc/suborg/en/node/5248>.

Resolución del Parlamento Europeo de 30 de abril de 2015 sobre la destrucción de los enclaves culturales perpetrada por ISIS/DAESH (2015/2649(RSP)): <http://www.europarl.europa.eu/ sides/getDoc.do? type $=$ TA\&reference $=$ P 8-TA-20150179\&language $=\mathrm{EN}>$.

Resolución ONU 2347 (2017): <https://www.unodc.org/ documents/organized-crime/mandates_on_trafficking_ in_cultural_property/resolution_2347/N1707909_S.pdf >.

\section{Normas}

Libia: Ley N. 3 de 1424 P.B. (1994) para la Protección de Antigüedades, Museos, Ciudades Antiguas y Edificios Históricos (29 de agosto, 1994) <http://www.unesco. org/culture/natlaws/media/pdf/libye/libya_cltherlaw_94_ arorof $>$.

Egipto: Ley N. 117 de 1983, sobre la Protección de Antigüedades <http:/www.unesco.org/culture/natlaws/ media/pdf/egypt/egypt_law117_1983_engtof.pdf>.

Turquía: Ley de Conservación del Patrimonio Cultural y Natural N. ${ }^{\circ} 2863$ de 23 de julio de 1983: <http://www. unesco.org/culture/natlaws/media/pdf/turkey/turkey_ lawconservationculturalnaturalproperty_1_entof $>$.

Tailandia: Ley sobre Monumentos Antiguos, Antigüedades, Objetos de Arte y Museos Nacionales, B.E.2504 (1961): <http://www.unesco.org/culture/ natlaws/media/pdf/thailande/thai_actcltmon_61_entof $>$.

Tailandia: Reglamento N. 3 (B.E.2504) de desarrollo de la Ley sobre Monumentos Antiguos, Antigüedades, Objetos de Arte y Museos Nacionales, B.E.2504 <http:// www.unesco.org/culture/natlaws/media/pdf/thailande/ thailande_act_1961_engl_orof.pdf>.

España: Ley de Patrimonio Histórico Español 16/1985 de 25 de junio <https://boe.es/diario_boe/txt. php?id=BOE-A-1985-12534>.

Unión Europea: Reglamento (UE) 2019/880 del Parlamento Europeo y del Consejo de 17 de abril de 2019 relativo a la introducción y la importación de bienes culturales <https://eur-lex.europa.eu/legal-content/ $\mathrm{ES} / \mathrm{TXT} /$ ? uri=uriserv:OJ.L_.2019.151.01.0001.01. SPA\&toc $=$ OJ:L:2019:151:TOC $>$. 